\title{
Regulation of gonadotropin subunit gene transcription
}

\author{
L L Burger, D J Haisenleder, A C Dalkin and J C Marshall \\ Division of Endocrinology, Department of Internal Medicine and the Center for Research in Reproduction, University of Virginia, Charlottesville, \\ VA 22908, USA \\ (Requests for offprints should be addressed to L L Burger; Email: Iburger@virginia.edu)
}

\begin{abstract}
Reproductive function in mammals is regulated by the pituitary gonadotropins luteinizing hormone (LH) and follicle-stimulating hormone (FSH). $\mathrm{LH}$ and $\mathrm{FSH}$ are secreted by the gonadotrope cell and act on the gonad in a sequential and synergistic manner to initiate sexual maturation and maintain cyclic reproductive function. The synthesis and secretion of $\mathrm{LH}$ and $\mathrm{FSH}$ are regulated mainly by the pulsatile release of the hypothalamic decapeptide hormone gonadotropin-releasing hormone $(\mathrm{GnRH})$. The control of differential LH and FSH synthesis and secretion is complex and involves the interplay between the gonads, hypothalamus and pituitary. In this review, the transcriptional regulation of the gonadotropin subunit genes is discussed in a physiologic setting, and we aimed to examine the mechanisms that drive those changes.
\end{abstract}

Journal of Molecular Endocrinology (2004) 33, 559-584

\section{Introduction}

Dynamic regulation of the pituitary gonadotropins luteinizing hormone $(\mathrm{LH})$ and follicle-stimulating hormone $(\mathrm{FSH})$ is essential for mammalian reproduction. $\mathrm{LH}$ and $\mathrm{FSH}$ are comprised of two glycoprotein subunits, $\alpha$ (common to both), and $\mathrm{LH} \beta$ and FSH $\beta$, which are coded by three genes located on separate chromosomes (Chin 1987, Gharib et al. 1990b). LH and FSH are secreted by the pituitary gonadotropes and act on the gonad in a sequential and synergistic manner to initiate sexual maturation and maintain cyclic reproductive function (Bäckström et al. 1982, Marshall \& Kelch 1986, Wu et al. 1990). The synthesis and secretion of the gonadotropins are regulated primarily by the hypothalamic decapeptide gonadotropin-releasing hormone $(\mathrm{GnRH})$, which is secreted into the hypophyseal-portal circulation in a pulsatile manner (Clarke \& Cummins 1982, Levine \& Ramirez 1982). The control of LH and FSH synthesis and secretion is complex and involves interplay between the gonads, pituitary and hypothalamus. LH and FSH act on the ovaries and the testes to regulate folliculogenesis, ovulation, spermatogenesis and steroidogenesis. Gonadal steroids and peptides, in turn, act at the hypothalamus and/or pituitary to regulate either positively or negatively LH and FSH synthesis and secretion. The aims of this review are to present the transcriptional regulation of the gonadotropin subunit genes in a physiologic setting and examine the mechanisms that drive those changes.

\section{Physiologic changes in subunit gene transcription}

\section{Estrous cycle}

Changes in gonadotropin subunit mRNA expression have been determined over the course of the estrous cycle in rats and mice. In rats, we have shown that LH $\beta$ and FSH $\beta$ mRNAs increase during the time of preovulatory gonadotropin surge. The increase in LH $\beta$ mRNA precedes that of FSH $\beta$; LH $\beta$ mRNA began increasing around $1400 \mathrm{~h}$, before the beginning of the LH surge; was maximal at $1700 \mathrm{~h}$; and had returned to basal by 
2200 h (Zmeili et al. 1986, Kerrigan et al. 1995). FSH $\beta$ mRNA did not increase until about $2200 \mathrm{~h}$, $2 \mathrm{~h}$ after the increase in serum FSH, and was maximal at $0200 \mathrm{~h}$ during estrus and had returned to basal by $0800 \mathrm{~h}$ (Ortolano et al. 1988). In contrast, $\alpha$ mRNA did not change during the preovulatory surge (Zmeili et al. 1986). The periovulatory changes in the $\beta$-subunit mRNAs are coincident with increased GnRH secretion (Levine \& Ramirez 1982) and result from increased gene transcription. $\beta$-subunit mRNA synthesis, as measured by nuclear run-on assays, was found to be greatest during proestrus for $\mathrm{LH} \beta$, and during late proestrus and estrus for FSH $\beta$ (Shupnik et al. 1989a). Similarly, FSH $\beta$ promoter activity was increased on estrus (versus metestrus) in transgenic mice harboring an ovine $\mathrm{FSH} \beta$ promoter-luciferase (LUG) reporter gene (Huang et al. 2001a,b).

In addition to the changes in subunit mRNAs that occur around the preovulatory gonadotropin surge, FSH $\beta$ mRNA expression increased at metestrus, and both $\alpha$ and LH $\beta$ mRNAs increased in parallel during diestrus, periods when serum LH and FSH levels are low. The mechanism(s) for the these changes are not well understood, but probably reflect the sensitivity of the subunit genes to differences in $\mathrm{GnRH}$ pulse frequencies and steroid milieu; and for FSH $\beta$, changes in serum and/or intrapituitary inhibin, activin or follistatin (FS).

\section{Gonadectomy}

Several studies have shown that gonadotropin subunit gene expression is differentially regulated after gonadectomy. The loss of negative feedback by sex steroids at the hypothalamus results in increased GnRH pulse amplitude and frequency (Levine \& Ramirez 1982). This increase in GnRH drives expression of all three subunit genes, but there are significant differences in the magnitudes of change and timing, both among the subunits and between the sexes.

In male rats, castration (CAST) results in a rapid increase in serum LH, reflecting an increase in $\mathrm{GnRH}$ secretion. Coincident with the increase in $\mathrm{GnRH}$, all three subunit mRNAs are elevated $24 \mathrm{~h}$ after CAST (Papavasiliou et al. 1986, Dalkin et al. 2001, Burger et al. 2004). Whereas $\alpha$ and LH $\beta$ mRNA concentrations continue to increase steadily after CAST (Papavasiliou et al. 1986, Dalkin et al.
1990), increases in FSH $\beta$ mRNA are more modest and begin to decline by day 7 (Gharib et al. 1987, Dalkin et al. 1990).

The increases in subunit mRNA after CAST are regulated in part at the level of transcription. We have recently investigated the changes in subunit gene transcription after CAST by measuring subunit primary transcript (PT) concentrations (Fig. 1). These transcripts are newly formed RNA that include both exon and intron sequences, prior to RNA splicing, and thus are closely linked to gene transcription and mRNA formation (Dalkin et al. 2001). After CAST, LH $\beta$ PT increases within $8 \mathrm{~h}$ and remains elevated (Dalkin et al. 2001, Burger et al. 2004). Similarly, LH $\beta$ promoter activity has been reported to increase after CAST in transgenic mice harboring either a rat $\mathrm{LH} \beta$ promoter-LUG construct (Fallest et al. 1995) or an ovine LH $\beta$-chloramphenicol acetyltransferase (CAT) reporter (McNeilly et al. 1996). Although FSH mRNA was elevated within $24 \mathrm{~h}$ of CAST, we did not observe an acute increase in FSH $\beta$ PT (Burger et al. 2004). However, FSH $\beta$ transcription was increased 5-7 days after CAST, as measured by either nuclear run-on assays (Paul et al. 1990), PT (Dalkin et al. 2001) or FSH $\beta$ promoter activity in transgenic mice carrying an ovine FSH $\beta$-LUG reporter gene (Huang et al. 2001a,b). In contrast, changes in endogenous $\alpha$ gene transcription after CAST are not consistent; we have reported that $\alpha$ PT was unchanged at day 7 (Dalkin et al. 2001), whereas $\alpha$ mRNA synthesis was increased on day 5 (Paul et al. 1990). Additionally, $\alpha$ promoter activity increased after CAST in transgenic mice carrying either a human or bovine $\alpha$ promoter-CAT reporter (Clay et al. 1993); in vitro, the activity of a human $\alpha$ promoter-LUC reporter was greater when transfected into pituitary cells from male rats that had been CAST for 7-21 days (versus intact male rats) (Colin et al. 1996).

The utilization of GnRH antagonists or androgens to suppress endogenous GnRH demonstrates that the increased subunit transcription after CAST is $\mathrm{GnRH}$ dependent. The synthesis rates of all three subunit mRNAs were no different between intact rats and 4-day CAST rats treated with a GnRH antagonist (Paul et al. 1990), and we have also shown that a GnRH antagonist suppresses both LH $\beta$ and FSH $\beta$ PT below intact levels within hours after CAST (Fig. 1) (Burger et al. 2004). Similarly, in transgenic mice, either GnRH 
cast

cast+A

(ast $+\mathbf{A}+\mathbf{T}$
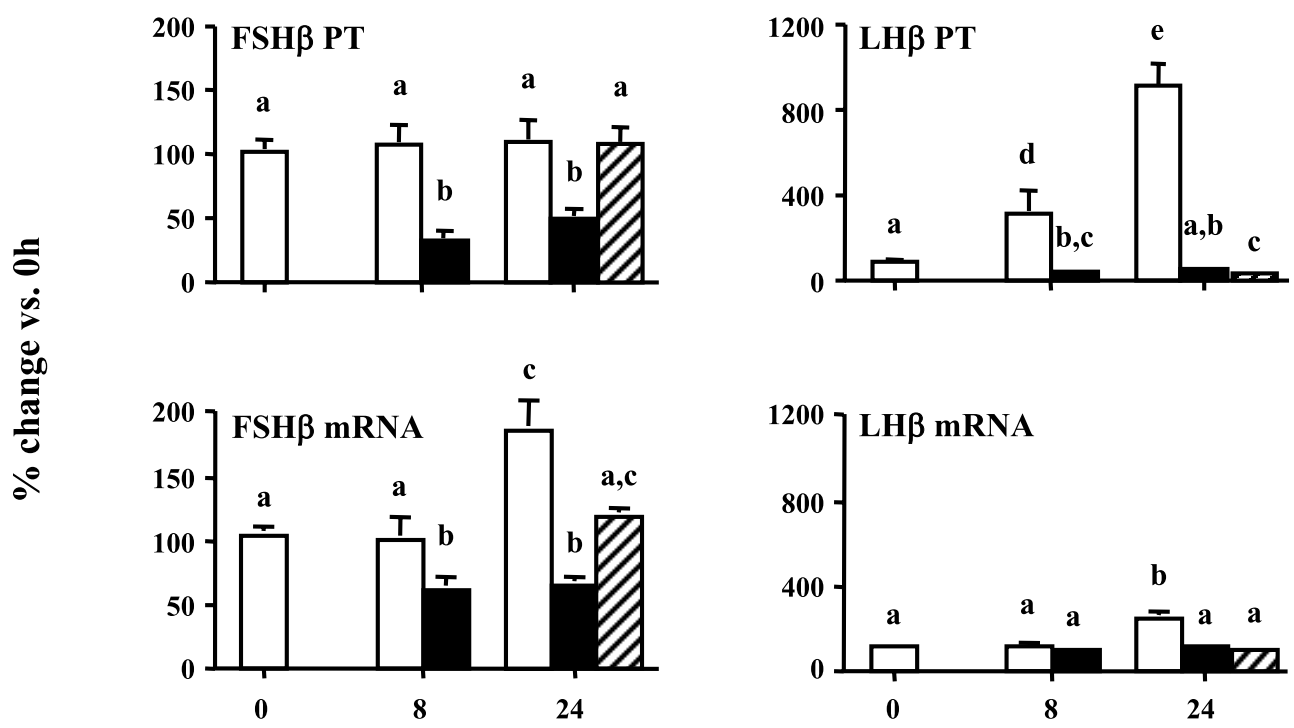

\section{hours after castration}

Figure 1 The effects of GnRH antagonist (A) and testosterone (T) on pituitary $\beta$-subunit primary transcripts (PT) in CAST male rats. Rats ( $n=5-10 /$ group) were CAST only or CAST and treated with GnRH antagonist LRF-147 (200 $\mu$ g, s.c.) every $12 \mathrm{~h}$ with and without silastic T implants (designed to achieve T levels of $3.5 \mathrm{ng} / \mathrm{ml}$ ). Rats were killed 0,8 and $24 \mathrm{~h}$ later. All data are presented as percent 0-h $( \pm$ S.E.) controls. Bars with different letters are significantly different $(P<0.05)$. Reproduced with permission from Burger et al. 2004.

antagonist or testosterone suppressed the postCAST increases in rat LH $\beta$-LUG (Fallest et al. 1995), ovine LH $\beta$-CAT (McNeilly et al. 1996), and both human and bovine $\alpha$-CAT promoter constructs (Clay et al. 1993). The elevated transcription rates seen after CAST require sustained GnRH input. Administration of a GnRH antagonist to 7-day CAST rats rapidly reduced LH $\beta$ and FSH $\beta$ PT, with half-disappearance times of $2 \cdot 7$ and 0.75 h respectively (Fig. 2) (Dalkin et al. 2001).

Gonadotropin subunit gene expression is also differentially regulated after ovariectomy (OVX). In female rats, serum LH rises more slowly after OVX and is not significantly elevated until days 2 or 3 (Dalkin et al. 1993, Burger et al. 2001). Coincident with the increase in GnRH, both $\alpha$ and LH $\beta$ mRNA expression begins to rise about day 3 , and continues to rise through day 21 (Dalkin et al. 1990, 1993, Burger et al. 2001). In contrast, both serum FSH and FSH $\beta$ mRNA increase rapidly after OVX; serum FSH doubles by $8 \mathrm{~h}$ and FSH $\beta$
mRNA by 30-60 min (Dalkin et al. 1993), and they continue to rise through day 7 (Dalkin et al. 1990, 1993, Burger et al. 2001). As in males, increased subunit mRNA levels result from elevated transcription rates; mRNA synthesis rates were increased for all three subunits in 30-day OVX rats (Shupnik et al. 1988). Recently, we have examined the changes in subunit transcription in the 7 days after OVX during the dynamic period after the loss of gonadal feedback (Fig. 3) (Burger et al. 2001). We found that LH $\beta$ PT concentrations were increased after day 3, paralleling changes in serum LH and LH $\beta$ mRNA. In contrast, there was a biphasic change in serum FSH, FSH $\beta$ mRNA and FSH $\beta$ PT after OVX, with an acute increase at 12-24 h, followed by an additional increase after $72 \mathrm{~h}$. Although $\alpha$ mRNA was elevated after OVX, as in our earlier studies in males, $\alpha$-PT did not change.

As in males, increased GnRH secretion after OVX is an important regulator of subunit 


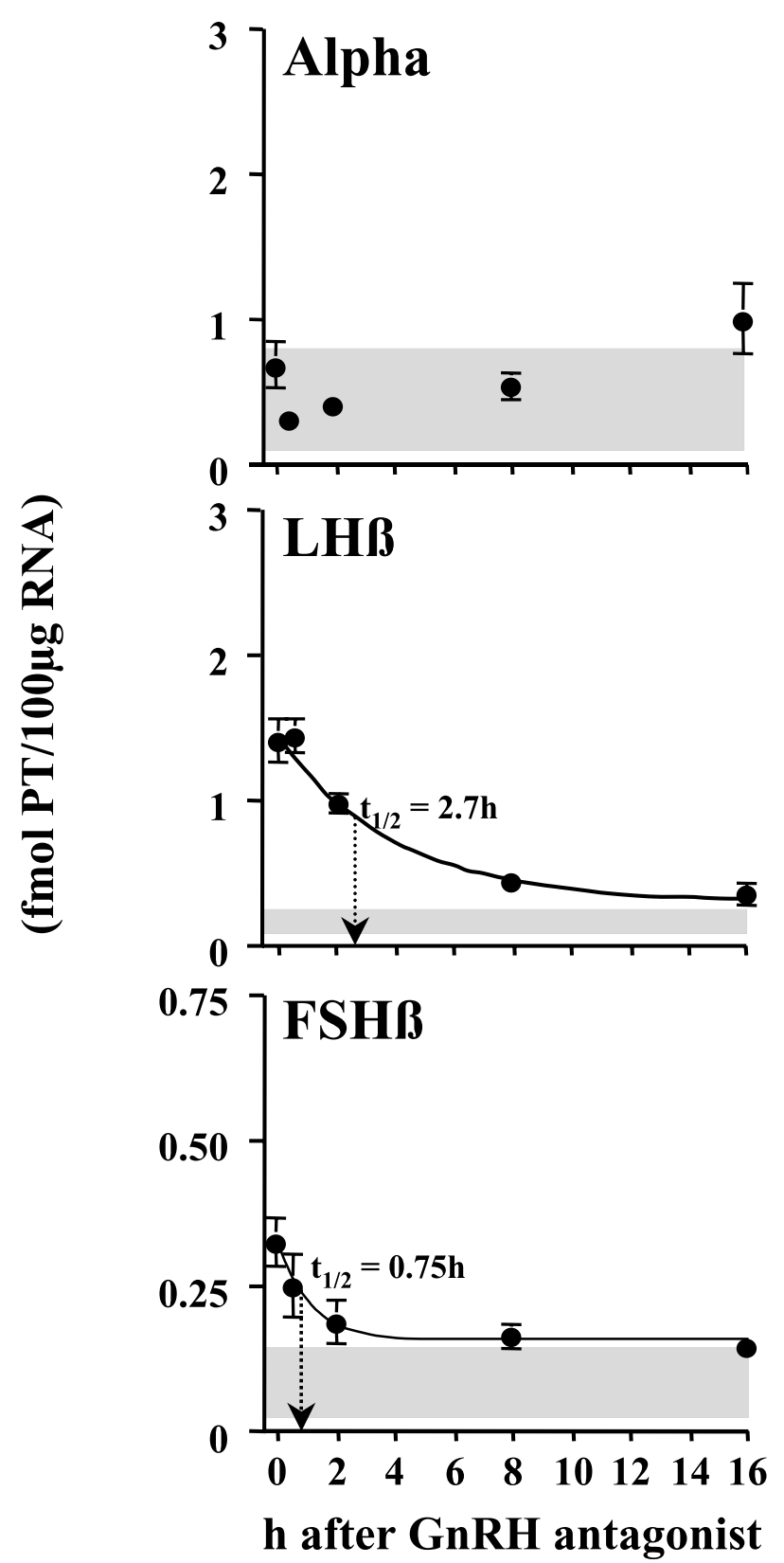

Figure 2 Disappearance rates for the gonadotropin subunit primary transcripts (PT) in 7-day CAST rats. PT concentration (fmol PT/100 $\mu \mathrm{g}$ RNA) is shown on the vertical axis, and time after $\mathrm{GnRH}$ antagonist treatment (h) is shown along the horizontal axis. The shaded areas represent the range observed in intact animals. The calculated $t_{1 / 2}$ for the $\mathrm{LH} \beta$ and $\mathrm{FSH} \beta$ subunits is displayed on the respective curves. Reproduced with permission from Dalkin et al. 2001. transcription. Suppression/blockade of GnRH by administration of either a GnRH antagonist or estradiol $\left(\mathrm{E}_{2}\right)$, in vivo, reduced $\alpha$ and $\mathrm{LH} \beta$ mRNA synthesis rates significantly, but had either no effect or a modest suppression on FSH $\beta$ in long-term OVX rats (Shupnik et al. 1988, 1990, Fallest \& Shupnik 1994). Similarly, we found that GnRH blockade prevented the post-OVX increase in LH $\beta$-PT, but had no effect on the acute (12-24-h) increase in FSH $\beta$-PT and only partially suppressed the increase in FSH $\beta$ PT after day 3 (Fig. 4). Sustained GnRH secretion is also required to maintain post-OVX increases in $\beta$-subunit transcription; giving a single dose of $\mathrm{GnRH}$ antagonist to 7-day OVX rats rapidly reduced both $\mathrm{LH} \beta$ and FSH $\beta$ PT, with half-disappearance times of 13 and 17 min respectively (Fig. 5).

While $\alpha$ and LH $\beta$ transcription after OVX appear to be largely regulated by GnRH, control of FSH $\beta$ transcription is more complex. The modest effect of either $\mathrm{GnRH}$ antagonist or $\mathrm{E}_{2}$ in suppressing FSH $\beta$ transcription in vivo, hinted at a role for inhibin, activin and/or FS. We previously showed that administration of inhibin- $\alpha$ antisera to intact female rats mimics the GnRH-independent increases in FSH and FSH $\beta$ mRNA that occur within hours after OVX (Dalkin et al. 1993, 1998). Similarly, we found that FSH $\beta$ PT levels increased rapidly after inhibin immunoneutralization and were suppressed in OVX rats treated with recombinant human inhibin, suggesting that inhibin suppresses FSH $\beta$ transcription (Burger et al. 2001). However, we also found that inhibin suppressed FSH $\beta$ mRNA levels much faster than after a GnRH antagonist, suggesting that inhibin may also affect FSH $\beta$ mRNA stability.

Several transgenic mouse models have been used to investigate the effects of OVX on subunit promoter activity. Hamernik et al. (1992) reported that $\mathrm{E}_{2}$ suppressed activity of either human $\alpha \mathrm{CAT}$ or bovine $\alpha \mathrm{CAT}$ constructs in OVX mice and that OVX levels could be restored with pulsatile GnRH. Activity of rat, ovine and bovine LH $\beta$ promoter-reporter constructs increased after OVX in transgenic mice, and were suppressed by either GnRH antagonist (Fallest et al. 1995, Quirk et al. 2001) or $\mathrm{E}_{2}$ (Fallest et al. 1995, McNeilly et al. 1996). Huang et al. (2001a,b) reported that FSH $\beta$ promoter activity is increased after OVX in transgenic mice harboring an ovine FSH $\beta$-LUG construct. 


\section{Primary Transcript (fmol PT/100 $\mu$ g RNA)}
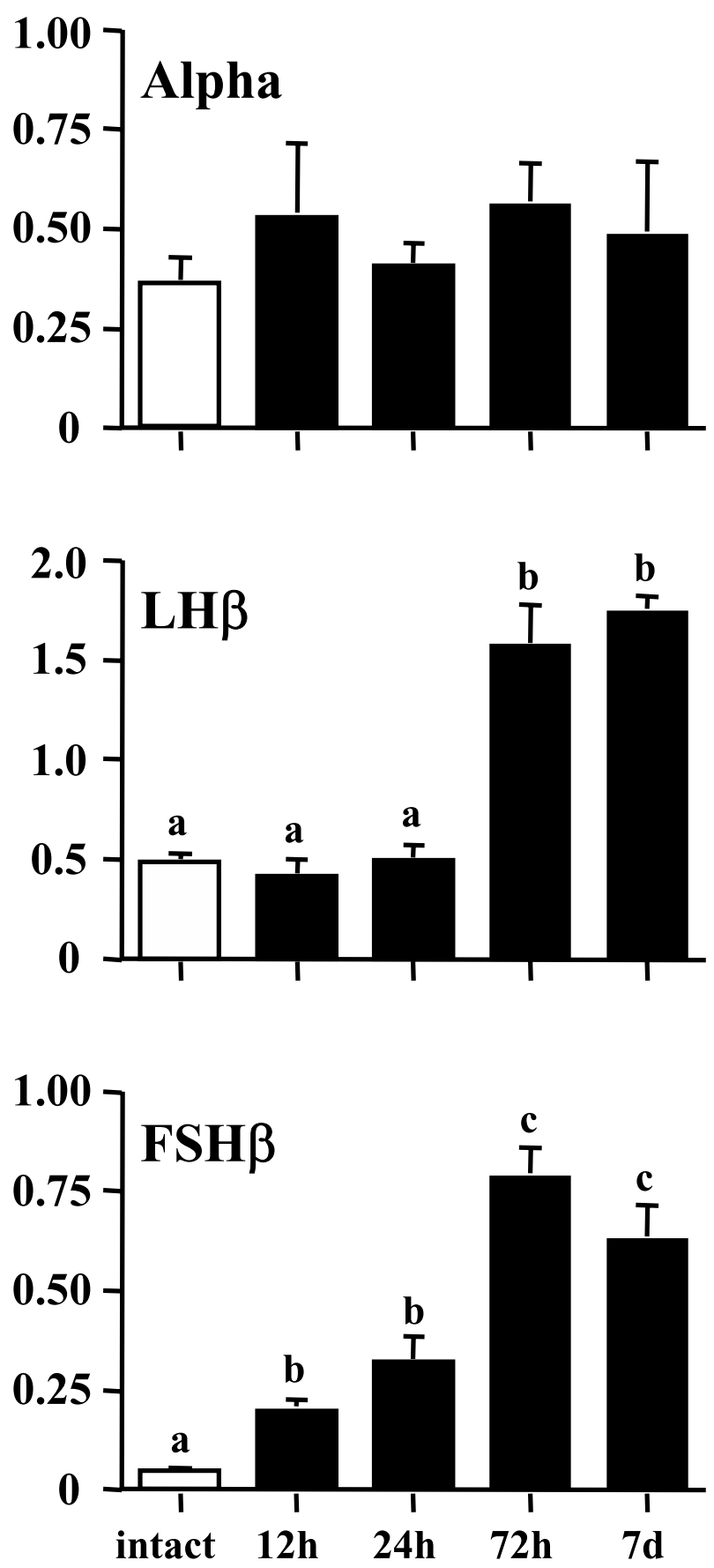

time after ovariectomy

www.endocrinology-journals.org
Gonadotropin subunit regulation by GnRH

\section{Physiologic changes in subunit transcription by pulsatile GnRH}

A central question in studying the physiology of the gonadotropins is how a single hormone $(\mathrm{GnRH})$ acting on a single cell type (gonadotrope) can differentially regulate two hormones (LH and FSH). The answer is that GnRH differentially regulates $\mathrm{LH}$ and FSH synthesis via changes in the pattern of GnRH pulse secretion. Our laboratory and others have investigated the effects of GnRH pulse amplitude and frequency on subunit mRNA expression both in vivo and in vitro. In GnRHdeficient male rats, fast-frequency GnRH pulses (every $8 \mathrm{~min}$ ) favored expression of $\alpha$ and, to a lesser extent, LH $\beta$ mRNA, fast-physiologic GnRH pulses (every $30 \mathrm{~min}$, the approximate frequency of GnRH pulses found in CAST male rats or intact female rats on the afternoon of proestrus (Levine \& Duffy 1988, Levin \& Ramirez 1982)) increased all three subunit mRNAs, and slow-frequency pulses (>120-min intervals) selectively increased FSH $\beta$ mRNA (Haisenleder et al. 1988, Dalkin et al. 1989, Kirk et al. 1994). GnRH pulse amplitude also differentially regulates subunit mRNA, though to a lesser extent than pulse frequency; only LH $\beta$ mRNA expression was sensitive to GnRH pulse amplitude and was maximally stimulated by GnRH pulse doses of $25 \mathrm{ng}$ or less (Haisenleder et al. 1988, Iliff-Sizemore et al. 1990).

GnRH regulation of subunit mRNA is somewhat different in female rats. In initial studies, we reported that GnRH pulses increased $\alpha$ and FSH $\beta$ mRNA levels, but not LH $\beta$ in GnRH-deficient OVX rats (Kerrigan et al. 1993), a finding which was consistent with the lack of LH $\beta$ mRNA response to $\mathrm{GnRH}$ reported in cultured pituitary cells from OVX rats (Weiss et al. 1990). Subsequently, we found that testosterone was required for GnRH pulses to increase LH $\beta$ mRNA in OVX rats, and that the optimal dose of

Figure 3 The changes in gonadotropin subunit primary transcript (PT) concentrations following OVX. Pituitaries were collected from intact rats or rats OVX for the indicated times. $n=5-9 /$ group. Each bar represents the mean \pm S.E. Bars with different letters are significantly $(P<0.05)$ different. Reproduced with permission from Burger et al. 2001. 


\section{Primary Transcript (fmol PT/100 $\mu$ g RNA)}
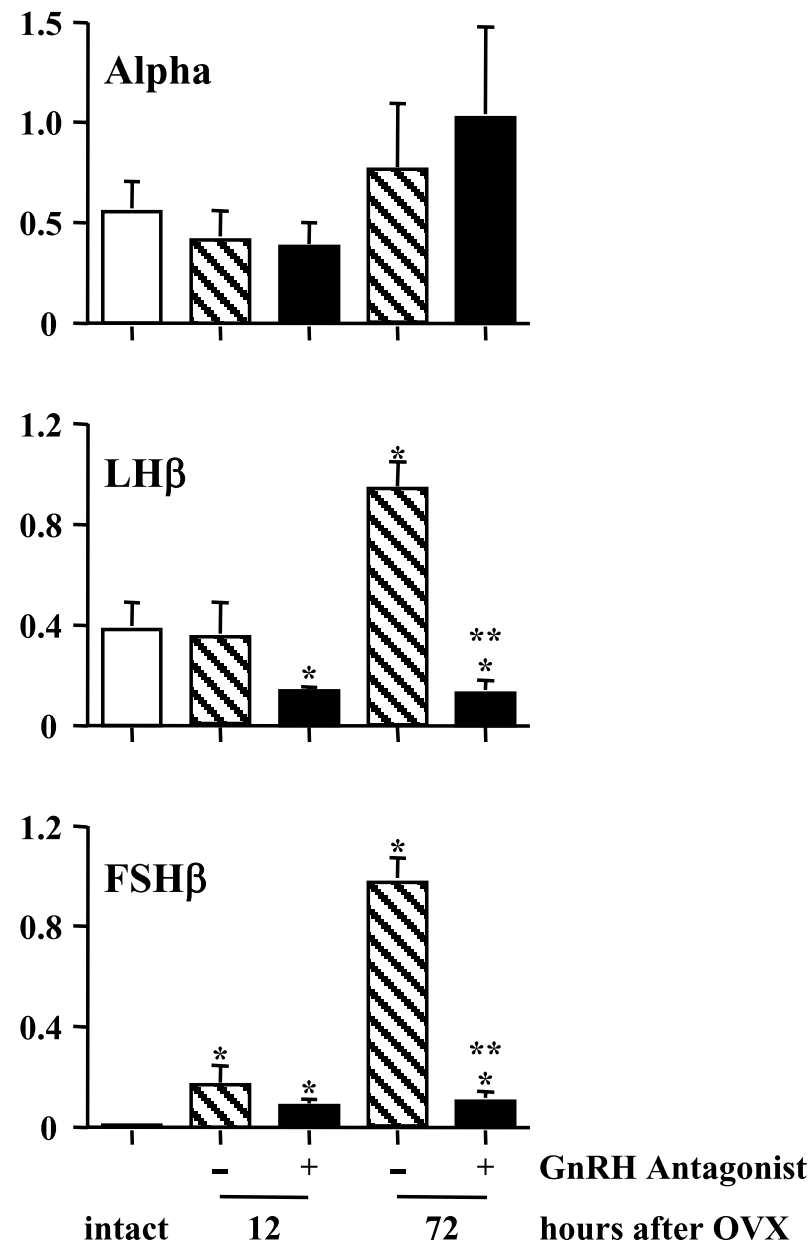

Figure 4 The effects of $\mathrm{GnRH}$ antagonist on gonadotropin subunit primary transcript (PT) concentrations after OVX. Pituitaries were collected from intact rats, and 12- and 72-h OVX rats treated either with the $\mathrm{GnRH}$ antagonist LRF-147 (+) or vehicle (-, BSA-saline) $n=5-7 /$ group. Each bar represents the mean \pm S.E. * Indicates means are significantly different $(P<0.05)$ from intact rats. ${ }^{* *}$ Indicates antagonist-treated group is significantly different $(P<0.05)$ from OVX (vehicle, -$)$ at the same time point. Reproduced with permission from Burger et al. 2001.

testosterone was similar to levels seen at proestrus (Yasin et al. 1996). Although testosterone is required in females, it is not acutely required in males, as GnRH increased LH $\beta$ mRNA in short-term CAST males with or without $\mathrm{T}$ (Yasin et al. 1996). On a background of proestrus $\mathrm{T}$ levels, we have found

\section{Primary Transcript

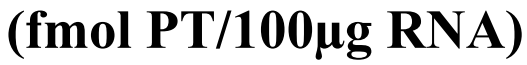
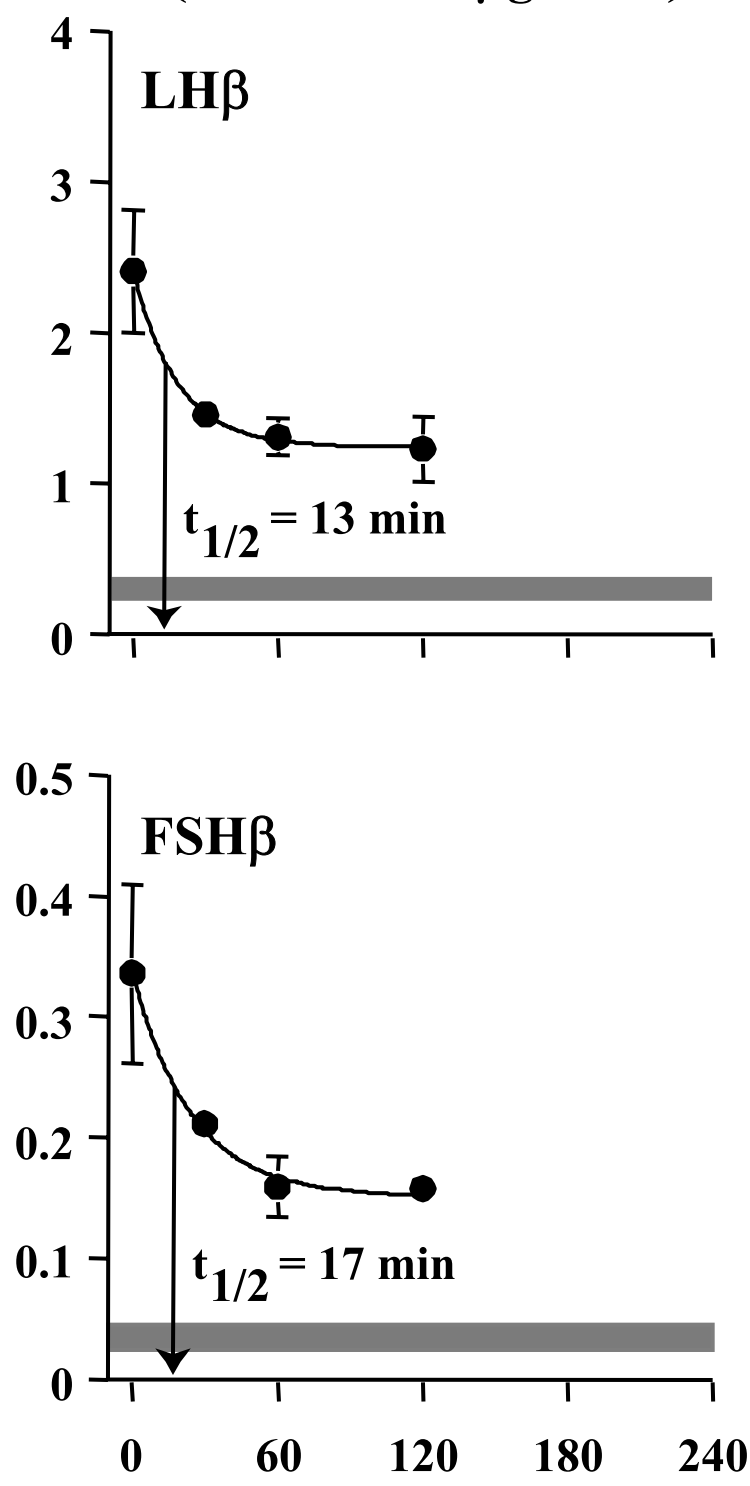

\section{minutes after GnRH antagonist}

Figure 5 The effects of GnRH antagonist on $\beta$-subunit primary transcript (PT) half-disappearance times $\left(t_{1 / 2}\right)$. Pituitaries were collected from 7-day OVX rats treated with the GnRH antagonist LRF-147 (30 $\mu$ g i.v.) and then killed $0,30,60$ or 120 min later ( $n=5-6 /$ time). Each point represents the mean \pm S.E. The shaded areas represent the mean \pm S.E. observed in intact rats. The calculated $t_{1 / 2}$ for $\mathrm{LH} \beta$ and $\mathrm{FSH} \beta$ primary transcripts is displayed on the respective curves. Reproduced with permission from Burger et al. 2001. 
that GnRH pulse amplitude and frequency differentially regulate subunit mRNA expression in females similar to males. Alpha and FSH $\beta$ mRNAs were increased by a wider range of $\mathrm{GnRH}$ pulse amplitudes, while LH $\beta$ mRNA was maximally stimulated by lower GnRH pulse doses (Dalkin et al. 1999). Fast-physiologic GnRH frequencies (8-120-min intervals) stimulated all three subunit mRNAs, but only slow-frequency GnRH pulses (every $240 \mathrm{~min}$ ) increased FSH $\beta$ (Dalkin et al. 1999). The effects of GnRH pulse amplitude and frequency have also been examined in cultured pituitary cells. In female rat pituitary cells, only $\alpha$ mRNA increased with high-amplitude $\mathrm{GnRH}$ pulses, whereas LH $\beta$ and FSH $\beta$ mRNAs responded to lower doses of GnRH (Haisenleder et al. 1993a). In male pituitary cells, $\alpha$ mRNA was increased by all GnRH pulse frequencies examined, LH $\beta$ mRNA was maximally stimulated by pulses every $30 \mathrm{~min}$, and FSH $\beta$ mRNA was greatest after 120-min pulses (Kaiser et al. 1997b).

Although there is some evidence that $\mathrm{GnRH}$ may regulate subunit mRNA concentrations via mRNA stability (Salton et al. 1988, Weiss et al. 1992), GnRH appears to exert its main action at the transcriptional level. While continuous GnRH stimulated $\alpha$ transcription in vitro (Shupnik 1990), a pulsatile GnRH input was required to increase $\beta$-subunit transcription both in vivo (Haisenleder et al. 1991) and in vitro (Shupnik 1990, Shupnik \& Fallest 1994). Furthermore, pulsatile GnRH increased $\beta$-subunit transcription in a frequencydependent manner. Faster GnRH pulse frequencies $(\geq 60$-min interpulse interval) preferentially increased LH $\beta$ mRNA synthesis or PT levels both in vitro (Shupnik 1996) and in vivo (Haisenleder et al. 1991, Burger et al. 2002). In contrast, slower GnRH pulse frequencies ( $\geq 60$-min intervals) preferentially increased FSH $\beta$ transcription. Alphasubunit transcription does not appear to be tightly regulated by GnRH pulse frequency, some studies indicating that $\alpha$ transcription is favored by fast-frequency GnRH pulses (Haisenleder et al. 1991, Shupnik et al. 1996), and others showing that fast and slow frequencies are equally effective (Haisenleder et al. 2001, 2003a, Burger et al. 2002).

The effects of a GnRH pulse on subunit transcription are both rapid and transient. In male rats, LH $\beta$ and FSH $\beta$ PTs increased six- and fourfold $5 \mathrm{~min}$ after a GnRH pulse, and declined to basal levels by $30 \mathrm{~min}$, with FSH $\beta$ PT decreasing faster than LH $\beta$ PT (Dalkin et al. 2001). Although $\alpha$ PT tended to increase 5-15 min after a GnRH pulse, the rise was not statistically significant. The duration of $\mathrm{GnRH}$ pulsatile treatment also appears to be important in regulating subunit transcription rates. In earlier studies, we found that GnRH pulses given every $30 \mathrm{~min}$ to male rats increased $\alpha$, LH $\beta$ and FSH $\beta$ mRNA synthesis rates, but that the increases in $\mathrm{LH} \beta$ and FSH $\beta$ returned to basal at 4-24 h (Haisenleder et al. 1991). In a more recent study, we found that only fast-frequency GnRH pulses (30 min) increased LH $\beta$ PT levels, and that the increase in transcription was sustained after 1-24 h of pulses (Fig. 6) (Burger et al. 2003). Unexpectedly, we found that both fast- and slow(240-min) frequency GnRH pulses increased FSH $\beta$ PT, but with significantly different time courses. Fast-frequency GnRH pulses transiently increased FSH $\beta$ PT after 1-6 h, but returned to control levels by $24 \mathrm{~h}$. In contrast, slow-frequency GnRH pulses resulted in a delayed but sustained increase in FSH $\beta$ PT at 8-24 h, and only 240-min pulses increased both FSH $\beta$ PT and mRNA expression.

A recent study investigated the effects of $\mathrm{GnRH}$ pulse frequency on subunit promoter activities in gonadotrope-derived L $\beta$ T2 cells and found similar results to those seen in vivo or in cultured pituitary cells (Bedecarrats \& Kaiser 2003). Fast-frequency GnRH pulses ( $\geq 60 \mathrm{~min}$ ) stimulated expression of a rat LH $\beta$ promoter-reporter to a greater degree than slower frequencies. In contrast, a rat FSH $\beta$ promoter-reporter was preferentially stimulated by slower $\mathrm{GnRH}$ pulse frequencies $(\geq 60 \mathrm{~min})$, but a clear preference for a slower $\mathrm{GnRH}$ frequency was not observed until after $20 \mathrm{~h}$ of pulses, before which fast $\mathrm{GnRH}$ frequencies were as effective if not better in stimulating FSH $\beta$ promoter activity (Bedecarrats \& Kaiser 2003). Alpha promoter activity was also stimulated by GnRH in L $\beta$ T2 cells but was less frequency dependent than the $\beta$-subunits; human $\alpha$-LUC reporter activity increased with all GnRH frequencies but was greatest with more frequent $\mathrm{GnRH}$ pulses (Bedecarrats \& Kaiser 2003).

\section{Intracellular mechanisms of subunit gene transcription by GnRH}

The GnRH receptor (GnRH-R) is a member of the seven-transmembrane receptor family, with receptor binding activating two specific 
GTP-binding proteins $\left(\mathrm{G}_{\mathrm{q}}, \mathrm{G}_{11}\right)$ (Hsieh \& Martin 1992, Stojilkovic \& Catt 1995b, Kaiser et al. 1997a, Liu et al. 2002b). GnRH-R activation stimulates increased phosphoinositide turnover and a rise in

\section{Primary Transcript}
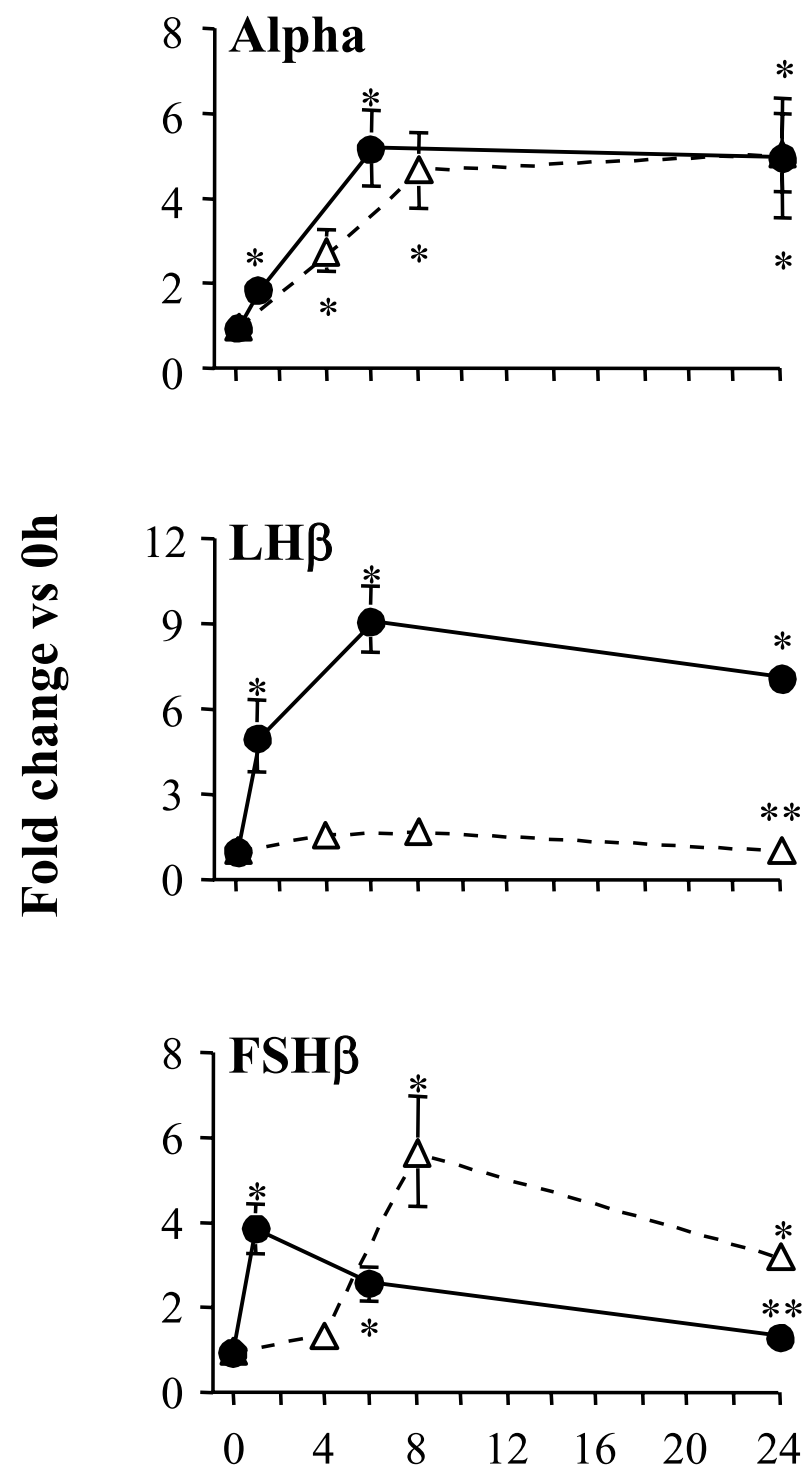

\section{hours of GnRH pulses}

\footnotetext{
- - GnRH pulses every $30 \mathrm{~min}$ -- $\Delta-\cdot$ GnRH pulses every $240 \mathrm{~min}$
}

intracellular diaclyglycerol levels, resulting in the activation of protein kinase $\mathrm{C}(\mathrm{PKG})$ (Andrews \& Conn 1986, Stojilkovic \& Catt 1995a). Activation of the GnRH-R also stimulates a transient rise in intracellular calcium, derived from inositol 1,4,5triphosphate-induced release from intracellular storage pools and from influx via voltagesensitive(L-type) channels (Naor 1990, Ando et al. 2001). GnRH also stimulates an increase in cAMP (Bourne 1988, Garrel et al. 1997) and activates members of the mitogen-activated protein kinase (MAPK) family, including extracellular signalregulated kinase (ERK) (Mitchell et al. 1994, Roberson et al. 1995, Sundaresan et al. 1996, Reiss et al. 1997), c-Jun $\mathrm{NH}_{2}$-terminal kinase (JNK) (Levi et al. 1998, Roberson et al. 1999, Yokoi et al. 2000) and p38 (Roberson et al. 1999, Liu et al. 2002a) in several species.

As discussed previously, gonadotropin subunit gene transcription is regulated in a differential manner by alterations in GnRH pulse frequency. Recent data suggest that various mammalian species express a second $\mathrm{GnRH}$ isoform (GnRH II) and GnRH-R (GnRH-R II) in the hypothalamus and pituitary (Neill 2002). Although effects on sexual behavior and preferential actions on FSH secretion have been described, the physiologic roles of these isoforms remain to be determined. The evidence to date suggests that differential synthesis and secretion of LH and FSH is the product of altered patterns of pulsatile GnRH I secretion by activation of pituitary GnRH-R I. Although the intracellular messengers responsible for transmitting frequency-dependent signals from the plasma membrane to the nucleus within the gonadotrope have yet to be fully characterized, recent findings have provided insights into critical sites in the signal transduction pathways involved.

Figure 6 The effects of fast- and slow-frequency GnRH pulses over $24 \mathrm{~h}$ on gonadotropin subunit primary transcripts (PT). CAST plus testosterone-replaced male rats were i.v. pulsed with $25 \mathrm{ng} \mathrm{GnRH}$ every 30 (fast) or 240 (slow) min for $1-24 \mathrm{~h}$ ( $n=4-8$ rats/observation). Data are expressed as fold change versus controls $(0 \mathrm{~h}) .{ }^{*}$ Indicates significant differences $(P<0.05)$ versus untreated, CAST plus testosterone $(\mathrm{T})$ controls $(0 \mathrm{~h})$. ** Indicates significant differences between $\mathrm{GnRH}$ pulse regimens at $24 \mathrm{~h}$. Reproduced with permission from Burger et al. 2002. 


\section{CAMP}

Activation of the cAMP pathway stimulates $\alpha$ (mouse, rat and human) promoter activity (Maurer et al. 1999), and cAMP may also have a general stimulatory response to $\mathrm{GnRH}$ signaling. The mouse GnRH-R promoter contains two cAMP responsive element-binding (CREB) sites, and increased cAMP/protein kinase A (PKA) activity enhanced mouse GnRH-R promoter activity in lactotropic GH3 cells stably transfected with rat GnRH-R cDNA (GGH3 cell lines) (Han \& Conn 1999, Lin \& Conn 1999). However, studies conducted in either gonadotrope-derived $\alpha \mathrm{T} 3$ cells or transgenic mice models reveal that PKC, MAPK and activator protein-1 (AP-1) play a more prominent role in $\mathrm{GnRH}$ regulation of the $\mathrm{GnRH}$ promoter (Norwitz et al. 1999, White et al. 1999, Ellsworth et al. 2003). In the human model, CREB plays an essential role in GnRH activation of the $\alpha$ promoter, and GnRH stimulates the phosphorylation of CREB (Delegeane et al. 1987, Duan et al. 1999). The porcine FSH $\beta$ promoter also contains a putative CREB site (Kato et al. 1999). We have conducted in vitro studies in rat pituitary cells to determine whether cAMP stimulates gonadotropin subunit mRNA (Haisenleder et al. 1992). The results demonstrated that a diffusible cAMP analog stimulated a rise in $\alpha$, but not $\mathrm{LH} \beta$ or $\mathrm{FSH} \beta$ mRNA. Of interest, we showed that the pattern of cAMP input was critical, as pulsatile, but not continuous, cAMP enhanced $\alpha$ mRNA expression. More recent studies suggest that the $\mathrm{cAMP} / \mathrm{PKA}$ pathway plays a role in cross-talk between specific intracellular messenger systems (that is, PKC and ERK) in response to GnRH stimulation (Garrel et al. 1997, Han \& Conn 1999, Lin \& Conn 1999, Fowkes et al. 2002).

\section{Calcium}

The GnRH-induced increases in intracellular calcium play an essential role in gonadotropin secretion (Naor 1990, Stojilkovic \& Catt 1995a,b). Studies in various species and experimental models have also shown that $\alpha, \operatorname{LH} \beta$ and $\operatorname{FSH} \beta$ gene expression are regulated by increases in intracellular calcium (Ben Menahem \& Naor 1994, Saunders et al. 1998, Weck et al. 1998). In the rat, calcium stimulates a rise in $\alpha, \mathrm{LH} \beta$ and $\mathrm{FSH} \beta$ mRNA levels (Ben Menahem \& Naor 1994, Haisenleder et al. $1993 b, 1997)$. Other reports reveal that calcium stimulates gonadotropin subunit transcriptional activation, including increases in $\alpha$ and LH $\beta$ transcription (as measured by nuclear run-on assay or promoter-luciferase construct assay) (Weck et al. 2000) and $\alpha$, LH $\beta$ and FSH $\beta$ PT (Haisenleder et al. 2001). In contrast, other investigations using GH3 cells that express GnRH-R (GGH3-1 cells) have shown that the response to calcium is selective, stimulating $\alpha$ but not LH $\beta$ and FSH $\beta$ (Saunders et al. 1998). Another report found that calcium suppresses GnRH- or PKC-induced rat LH $\beta$ promoter activity in L $\beta \mathrm{T} 4$ cells (Vasilyev et al. 2002a). The reasons for these different gonadotropin subunit responses to calcium remain to be determined. However, it is likely that factors such as differences in cell model, promoter constructs used, experimental paradigms and the end products measured play a role in the outcomes seen.

Gonadotrope cells express spikes and oscillations in intracellular calcium, the patterns of which are altered by $\mathrm{GnRH}$ and linked to $\mathrm{LH}$ secretion (Holl et al. 1988, Tse \& Hille 1992, Stojikovic \& Catt 1995b). These observations are of interest, as in other cell types, alterations in intracellular calcium can play a role in the regulation of gene expression and activation of downstream mediators of signal transduction pathways (that is, ERK and calcium/ calmodulin-dependent kinase II (Ca/CaMK II)) (Villalobos et al. 1988, Gu \& Spitzer 1995, Dolmetsch et al. 1997, De Koninck et al. 1998, Durham \& Russo 2000). We have investigated whether alterations in intracellular calcium are involved in transmission of frequency-dependent signals from the plasma membrane to the nucleus, and whether these signals mediate the $\alpha, \mathrm{LH} \beta$ and FSH $\beta$ transcriptional responses to pulsatile GnRH (Haisenleder et al. 2001). The model used cultured rat pituitary cells and pulses of the calcium channel activator, Bay K 8644, plus potassium chloride $(\mathrm{BK}+\mathrm{KCl})$ given at intervals of 15,60 or $180 \mathrm{~min}$ for $6 \mathrm{~h}$. Gonadotropin subunit PT was measured to determine transcriptional responses to treatment. $\mathrm{BK}+\mathrm{KCl}$ pulses stimulated release of both $\mathrm{LH}$ and FSH with a similar pattern and magnitude to those seen after pulsatile GnRH. Alterations in the frequency of calcium pulse signals revealed that $\alpha$ was selectively stimulated by faster (every $15 \mathrm{~min}$ ) pulses of $\mathrm{BK}+\mathrm{KCl}$, with slower pulses being ineffective (Fig. 7). LH $\beta$ PT was stimulated by 15or 60-min pulses, but not 180-min pulses, of 


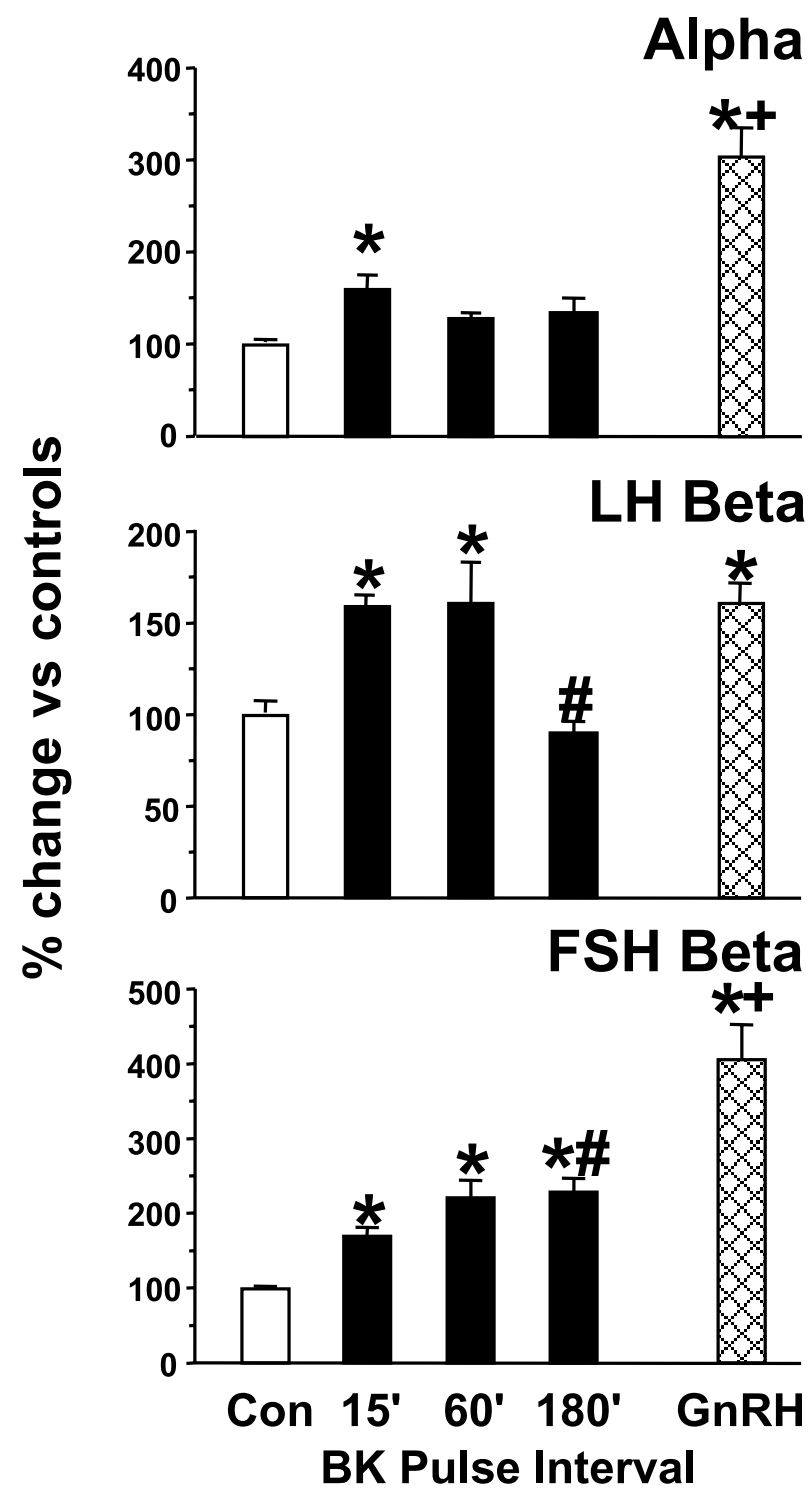

Figure 7 Effect of the calcium channel activator Bay $\mathrm{K}$ 8644 (BK) pulse interval $(15,60$ or $180 \mathrm{~min})$ on $\mathrm{LH} \beta$, and $\mathrm{FSH} \beta$ primary transcript (PT) levels. Pulse treatments were given for $6 \mathrm{~h}$, and a $\mathrm{GnRH}$ pulse group (60-min interval) was included for comparison. Results are expressed as the percent change versus vehicle-pulsed controls (Con). Means \pm S.E.M. are shown; note the different scale for each panel. The number of chambers per group was 10-12, derived from four or five separate experiments. ${ }^{*} P<0.05$ versus control, $\# P<0.05$ versus $15^{\prime}$ pulse $B K$ group; ${ }^{+} P<0.05$ versus peak BK treatment group. Reproduced with permission from Haisenleder et al. 2001.

$\mathrm{BK}+\mathrm{KCl}$. In contrast, FSH $\beta$ PT was maximally stimulated by the slower (180-min) pulse interval. This pattern of divergent gonadotropin subunit responses to pulse frequency is similar to previous findings for GnRH (Haisenleder et al. 1997). Thus, intermittent changes in intracellular calcium appear to be important in the transmission of GnRH signals, and may mediate the differential actions of pulse frequency on gonadotropin subunit gene expression.

The downstream mediators of calcium action within the gonadotrope have yet to be characterized. Among the putative candidates is $\mathrm{Ca} / \mathrm{CaMK}$ II, which is an important mediator of calcium signaling in several cell types, including the pituitary (Miller \& Kennedy 1986, Hanson \& Schulman 1992, Gui et al. 1994, 1996, Schulman et al. 1995, Nowakowski et al. 1997). We have examined this issue in both primary pituitary and LßT2 cells (Haisenleder et al. 2003a,b). GnRH stimulated $\mathrm{Ca} / \mathrm{CaMK}$ II activity, and activation was mediated via increases in intracellular calcium derived from cellular storage pools and influx from plasma membrane calcium channels. Moreover, inhibition of $\mathrm{Ca} / \mathrm{CaMK}$ II activation by administering a specific blocker, KN-93, partially suppressed GnRH-induced increases in $\alpha, \mathrm{LH} \beta$ and FSH $\beta$ PT (Fig. 8) or rat $\alpha$ and LH $\beta$ promoter activity. These finding support the hypothesis that $\mathrm{Ca} / \mathrm{CaMK}$ II is a downstream mediator of $\mathrm{GnRH/calcium} \mathrm{signaling} \mathrm{within} \mathrm{the} \mathrm{gonadotrope.}$

\section{Protein kinase $C(P K C)$}

Several investigations have shown that GnRH activates $\mathrm{PKC}$, and that cross-talk between $\mathrm{PKC}$, calcium and other intracellular pathways regulates gonadotropin secretion and mRNA expression (Naor 1990, Stojilkovic \& Catt 1995b, Kaiser et al. 1997a, Ando et al. 2001). Studies in rat pituitary cells reveal that PKC stimulates a rise $\alpha, \mathrm{LH} \beta$ and FSH $\beta$ mRNAs and $\alpha$ transcription (Ben Menahem \& Naor 1994, Weck et al. 1998, Halvorson et al. 1999, Vasilyev et al. 2002a). We have shown that PKG stimulates $\alpha$ and LH $\beta$ gene expression in rat pituitary cells in vitro; however, unlike results seen for cAMP and calcium, a pulsatile signal pattern does not play a significant role (Haisenleder et al. 1995). Data from other investigations in gonadotrope-derived L $\beta \mathrm{T} 2$, L $\beta \mathrm{T} 4$ or $\alpha \mathrm{T} 3$ cells, or lactotrope-derived GGH3-1 cells, demonstrate that PKG mediates the $\alpha$, LH $\beta$ and FSH $\beta$ transcriptional response to GnRH (Sundaresan et al. 1996, Weck et al. 1998, Vasilyev et al. 2002a,b). Kaiser 


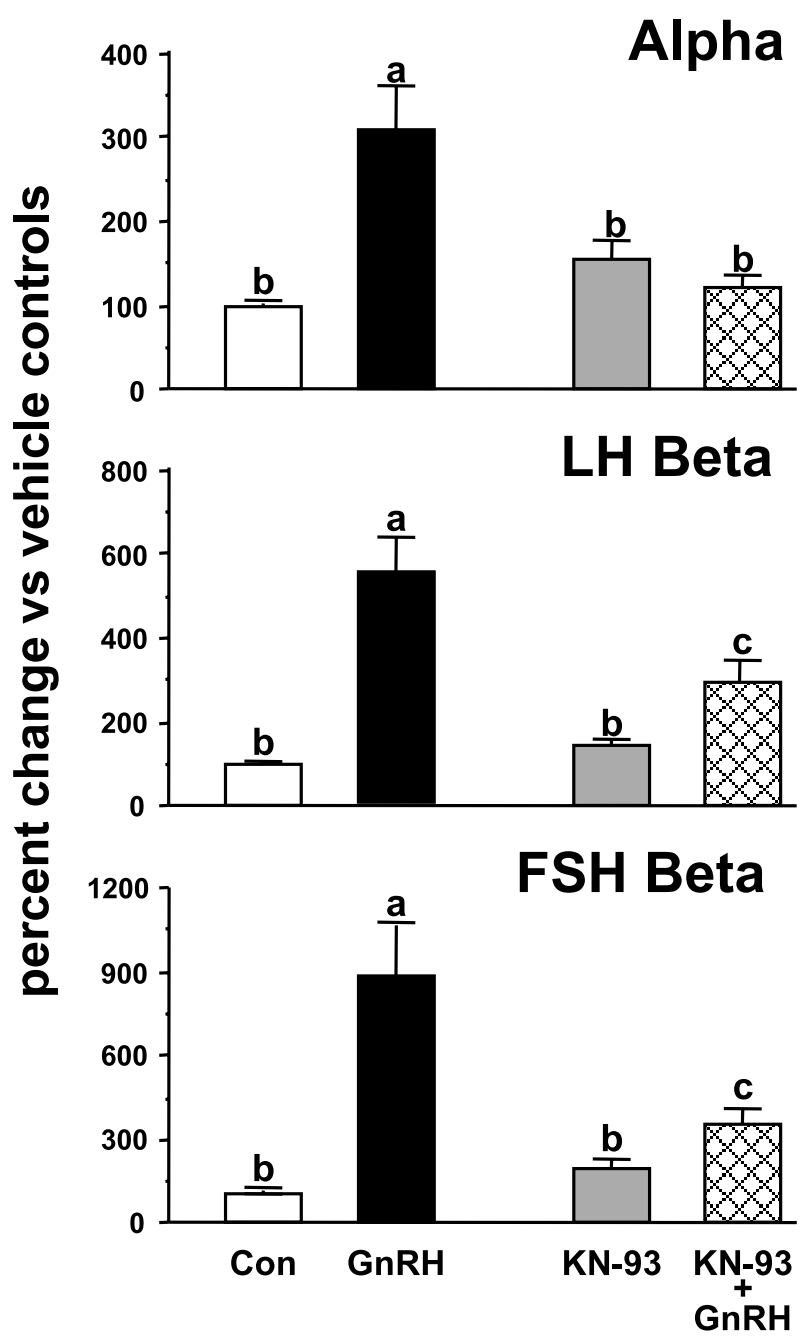

Figure $8 \alpha$, LH $\beta$ and FSH $\beta$ primary transcript (PT) responses to pulsatile $\mathrm{GnRH}$ with and without the Ca/CAMK II-specific inhibitor, KN-93 (10 $\mu \mathrm{M})$. Rat pituitary cells received pulses of $\mathrm{GnRH}$ (200 pM, 60-min intervals) for $24 \mathrm{~h}$. Results are expressed as the percent change versus medium-pulsed controls (Con). Note the different scale for each panel. Groups marked with different letters ( $\mathrm{a}, \mathrm{b}$ or $\mathrm{c}$ ) are statistically different $(P<0.05)$. Reproduced with permission from Haisenleder et al. 2003a.

et al. (2000) reported that PKG stimulation of the rat $\mathrm{LH} \beta$ gene is mediated via actions on Egr-1 binding within the proximal $\mathrm{GnRH}$ responsive region of the $\mathrm{LH} \beta$ promoter. An investigation of the bovine LH $\beta$ promoter showed that interactions between Egr-1, SF-1 and Ptx-1 mediate the response to PKC (Tremblay \& Drouin 1999). PKC has also been shown to stimulate the expression of the Egr-1 gene (Wolfe \& Call 1999). In contrast, $\alpha$-subunit transcriptional responses to $\mathrm{PKC}$ reflect activation of the MAPK pathway (as discussed below). Characterization of the ovine FSH $\beta$ promoter showed that $\mathrm{PKG}$ activation is mediated through multiple responsive regions, including 2 AP-1 sites (Strahl et al. 1998). However, these sites do not appear to play an important role in regulating the ovine FSH $\beta$ promoter in transgenic mice (Huang et al. 2001b). Of interest, responses of individual gonadotropin subunits to $\mathrm{PKC}$ stimulation have been shown to differ between published reports, posssibly reflecting differences in cell model or experimental paradigm (Saunders et al. 1998, Weck et al. 1998, Vasilyev et al. 2002a,b).

\section{Mitogen-activated protein kinase (MAPK)}

A number of investigators have shown that GnRH stimulates activation of various members of the MAPK family, including ERK 1 and 2 (Mitchell et al. 1994, Roberson et al. 1995, Sundaresan et al. 1996, Reiss et al. 1997), JNK (Levi et al. 1998, Roberson et al. 1999, Yokoi et al. 2000) and p38 (Roberson et al. 1999, Liu et al. 2002a). GnRHinduced activation of ERK is mediated through both PKC-dependent and PKC-independent pathways, including calcium (Roberson et al. 1995, Sundaresan et al. 1996, Reiss et al. 1997, Mulvaney et al. 1999). Moreover, ERK phosphorylates various transcription factors that may play roles in the regulation of gonadotropin subunit gene expression (such as c-Fos, c-Jun and the Ets protein - ELK-1 (Seger \& Krebs 1995, Maurer et al. 1999, Liu et al. 2002a).

We conducted studies to determine whether ERK plays a role in the differential gonadotrope responses to physiologic $\mathrm{GnRH}$ stimulation (Haisenleder et al. 1998). Initial work examined whether a pulsatile signal pattern is required to maintain ERK responsiveness to GnRH over longer durations. Groups of adult GnRH-deficient rats were given pulses of GnRH every $60 \mathrm{~min}$ for 1-8 $\mathrm{h}$ in vivo, and were compared with animals that received a continuous GnRH infusion for the same duration. Pulsatile GnRH stimulated a two- to fourfold increase in ERK activity, which was maintained over the 8-h experimental duration. However, continuous GnRH stimulated a transient rise in ERK only for the initial $2 \mathrm{~h}$ (Fig. 9). Follow-up studies showed that ERK activity is sensitive to $\mathrm{GnRH}$ pulse frequency, with slower 


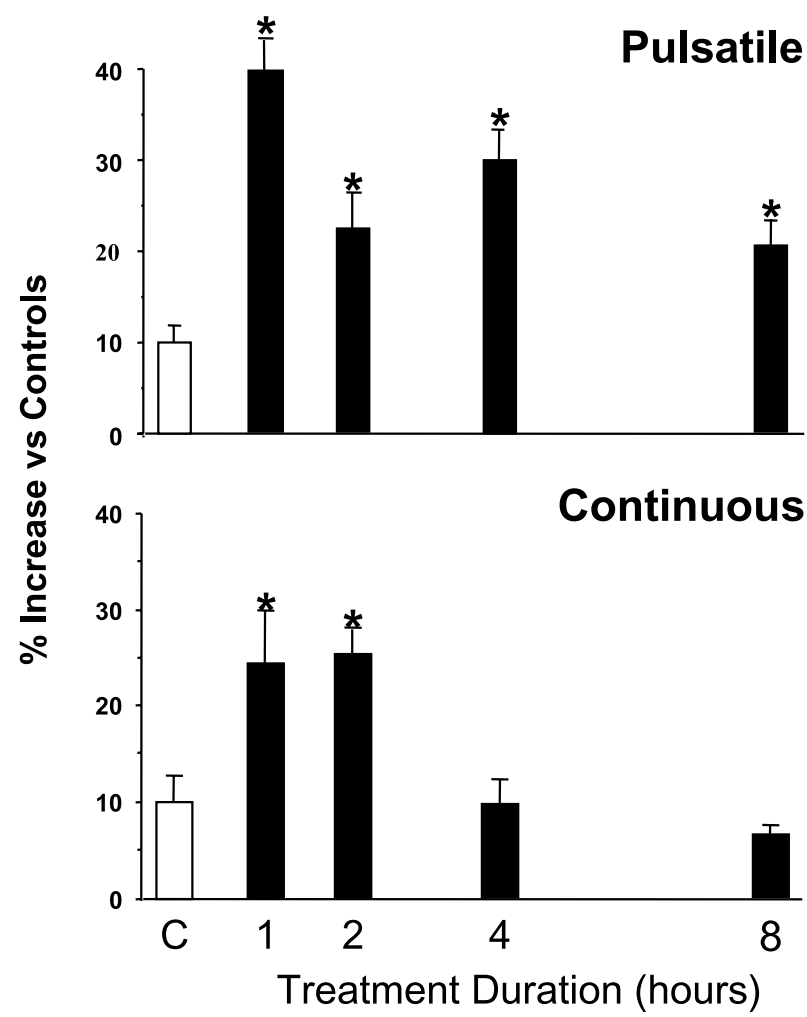

Figure 9 ERK responses to pulsatile or continuous $\mathrm{GnRH}$ after 1, 2, 4 or $8 \mathrm{~h}$. GnRH was administered to adult male rats either in a pulsatile (50 ng/pulse, 60-min interval) or continuous manner $(25 \mathrm{ng} / \mathrm{min}$; this dose was selected to provide sustained levels of circulating $\mathrm{GnRH}$ similar to peak levels obtained after a single 50 -ng pulse (that is, $200 \mathrm{pg} / \mathrm{ml}$ )). Controls (C) received BSA-saline pulses or a continuous infusion for $8 \mathrm{~h}$. The means \pm S.E.M. are shown ( $n=3$ /group, except in the pulsatile control group, in which $n=4$. * $P<0.05$ versus controls. Reproduced with permission from Haisenleder et al. 1998.

(120-min) interval pulses being more effective than faster (30- or 60-min) interval pulses. To determine the role of ERK in mediating GnRH-induced stimulation of gonadotropin subunit gene expression, GnRH pulses were administered to rat pituitary cells in vitro, with or without the ERK inhibitor, PD-098059 (PD). As shown in Fig. 10, PD blocked the GnRH-induced rise in $\alpha$, FSH $\beta$ and GnRH-R mRNAs, but not LH $\beta$. This suggests that $\mathrm{GnRH}$-induced stimulation of LH $\beta$ utilizes a distinct and different intracellular pathway or pathways. It is interesting to note that ERK is maximally stimulated by slower GnRH pulse intervals, and plays an important role in regulating the expression of two gonadotrope genes that are also maximally stimulated by slower $\mathrm{GnRH}$ pulse intervals (FSH $\beta$ and GnRH-R).

GnRH activation of the JNK pathway is mediated through PKC activation of the protein tyrosine kinase - cSrc (Levi et al. 1998). Recent findings suggest that JNK plays a role in the regulation of the rat $\mathrm{LH} \beta$ promoter, via actions on the proximal GnRH-responsive region of the gene (Yokoi et al. 2000). The p38 pathway has also been implicated in the activation of various transcription factors, including c-Jun, c-Fos and Elk-1 (Ham et al. 1997, Whitmarsh et al. 1997, Roberson et al. 1999). Experiments using $\alpha \mathrm{T} 3$ cells revealed that PKC mediates the GnRH-induced activation of p38 (Roberson et al. 1999). However, while p38 activates downstream pathways known to stimulate $\alpha$ gene expression (Maurer et al. 1999), published reports suggest that the signal transduction protein does not stimulate $\alpha$ promoter activity (Roberson et al. 1999). Whether p38 regulates the expression of the LH $\beta$ and FSH $\beta$ genes remains to be determined.

In summary, present information suggests that differential regulation of gonadotropin subunit gene expression by GnRH involves several mechanisms. GnRH may exert selective actions on specific signal transduction pathways (such as ERK regulation of $\alpha$ and FSH $\beta$, but not LH $\beta$ ). Alternatively, the responses may reflect differential sensitivity to intracellular messenger systems (for example, specific gonadotropin subunit genes may be more sensitive to calcium or PKC pathways than other subunit genes). Furthermore, it is likely that the role played by $\mathrm{GnRH}$ pulse frequency is selectively to activate one or more intracellular signal transduction pathways that are optimal for a specific gonadotropin subunit gene.

\section{Regulation of subunit gene transcription by steroids}

Steroids regulate gonadotropin subunit gene expression by acting either at the hypothalamus to alter GnRH pulsatility or directly on the pituitary gonadotropes. Differential regulation of the subunit genes by steroids was first reported in gonadectomized (GDX) animals. Both $\mathrm{E}_{2}$ and testosterone suppressed the post-GDX increases in pituitary $\alpha$ and LH $\beta$ mRNAs. In contrast, the post-OVX increase in FSH $\beta$ mRNA was only 


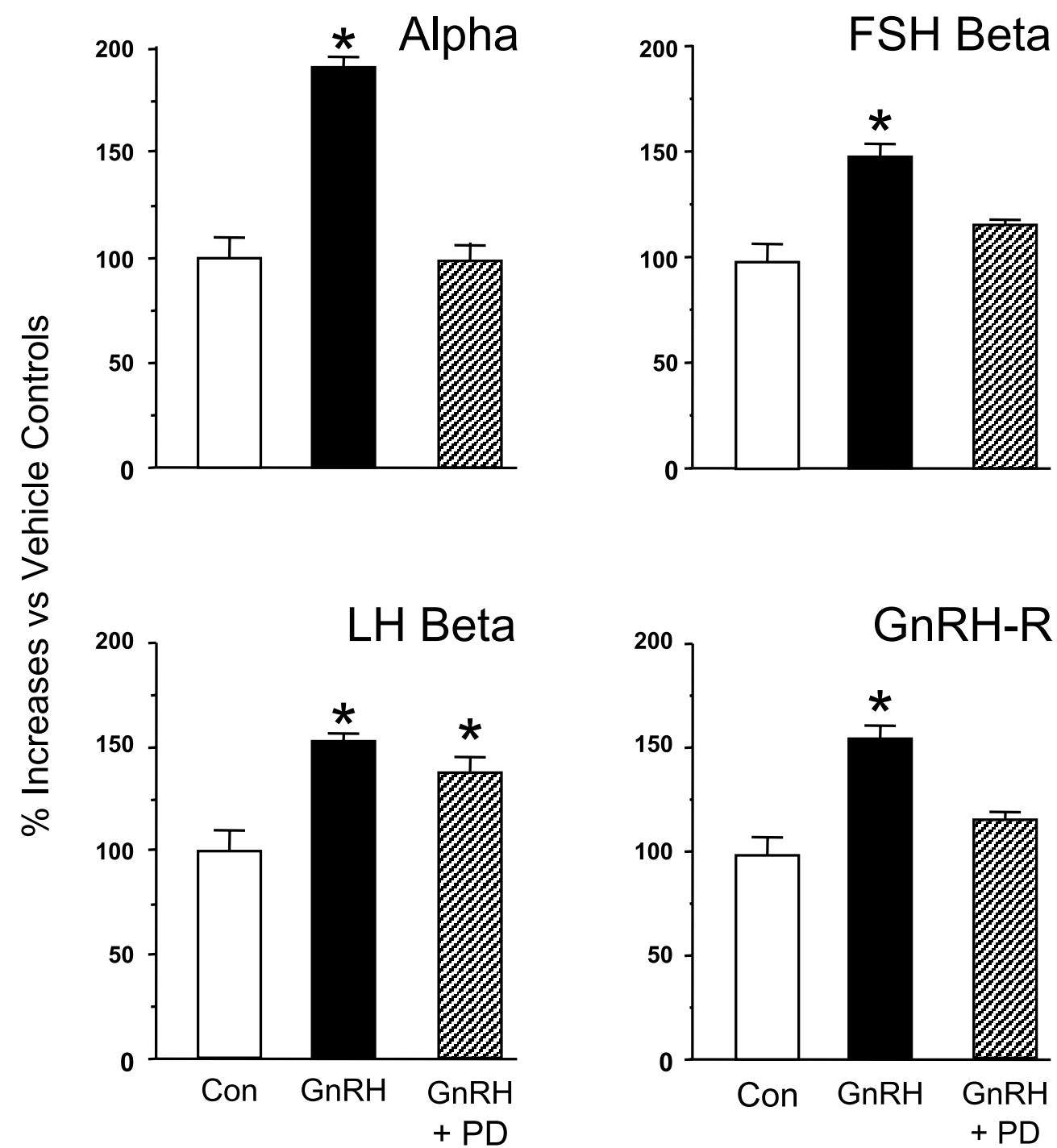

Figure 10 Gonadotrope mRNA responses to pulsatile GnRH (peak chamber concentration, $100 \mathrm{pg} / \mathrm{ml}$ ) given every $60 \mathrm{~min}$ for $24 \mathrm{~h}$ in the presence of PD-098059 (PD) or vehicle in perifused male pituitary cells ( $n=4 /$ group). The data are presented as the percent change versus medium-pulsed controls (Con). Reproduced with permission from Haisenleder et al. 1998.

partially reduced by $\mathrm{E}_{2}$ or $\mathrm{E}_{2}$ plus progesterone $\left(\mathrm{P}_{4}\right)$, reflecting the importance of ovarian inhibin in suppressing FSH $\beta$ expression (Gharib et al. 1987, Dalkin et al. 1990, 1993); in CAST rats, testosterone either had no effect or enhanced FSH $\beta$ responses in a dose-dependent manner (Gharib et al. 1987, 1990a, Wierman et al. 1988, 1990, Iliff-Sizemore et al. 1990). Experiments in GDX plus $\mathrm{GnRH}$ antagonist-treated rats, to eliminate the effects of steroids on GnRH secretion, largely show that in vivo steroids inhibit both $\alpha$ and LH $\beta$ gene expression by suppressing GnRH. In contrast, the regulation of FSH $\beta$ by steroids appears to be more complex.

\section{a-subunit}

In vivo, $\mathrm{E}_{2}$ markedly suppresses $\alpha$-subunit gene transcription. It inhibited the post-OVX increase in $\alpha$-subunit mRNA synthesis (Shupnik et al. 1988), and suppressed the post-OVX or -CAST increases in $\alpha$ promoter activity in transgenic mice harboring either a human or bovine $\alpha$ promoter-reporter construct (Keri et al. 1991, Hamernik et al. 1992, 
Clay et al. 1993). However, there is evidence that the suppression of $\alpha$ subunit transcription by $E_{2}$ is largely indirect. Shupnik et al. determined that $\mathrm{E}_{2}$ reduces $\alpha$ transcription in vivo largely by suppressing hypothalamic $\mathrm{GnRH} ; \mathrm{E}_{2}$ had no effect on $\alpha$-subunit mRNA synthesis in rat pituitary cells in vitro (Shupnik et al. 1989a, Shupnik 1996) or in OVX rats treated with GnRH antagonist (Shupnik \& Fallest 1994). Additionally, a functional estrogen response element (ERE) in the human $\alpha$ promoter has not been identified (Keri et al. 1991), and $\mathrm{E}_{2}$ does not affect human $\alpha$ promoter-reporter activity in $\alpha \mathrm{T} 3$ cells, even in the presence of an exogenous human estrogen-receptor (ER) (Clay et al. 1993). Although it appears that $\mathrm{E}_{2}$ regulates $\alpha$ transcription largely via hypothalamic $\mathrm{GnRH}$, it may also have a direct effect on the pituitary. Colin et al. (1996) reported that $\mathrm{E}_{2}$ suppressed basal activity of a human $\alpha$-promoter-LUG construct in the pituitaries of OVX transgenic mice, but enhanced $\mathrm{GnRH}$ responsiveness. We and others have also observed that $\mathrm{E}_{2}$ potentiates $\mathrm{GnRH}$ stimulation of $\alpha$ gene expression, but it is unknown whether the effect is direct or indirect (that is, increasing $\mathrm{GnRH}$ receptor numbers) (Mercer et al. 1989, Dalkin et al. 1990, Kerrigan et al. 1993, Turgeon et al. 1996, Kawakami \& Winters 1999).

In vivo, progesterone $\left(\mathrm{P}_{4}\right)$ potentiates the suppressive effects of $\mathrm{E}_{2}$ on $\alpha$-subunit mRNA, largely via decreased GnRH secretion (Simard et al. 1988, Dalkin et al. 1990). The effects of $\mathrm{P}_{4}$ directly on the pituitary are mixed; $\mathrm{P}_{4}\left(+\mathrm{E}_{2}\right)$ reduces $\alpha$ mRNA in OVX, hypothalamically disconnected ewes (Di Gregorio \& Nett 1995), and either reduces (Dalkin et al. 1990) or has no effect in the rat (Kerrigan et al. 1993). Little is known about $\mathrm{P}_{4}$ actions on $\alpha$-subunit transcription; however, neither $\mathrm{P}_{4}$ nor the $\mathrm{P}_{4}$ receptor antagonist RU486 modulated $\mathrm{E}_{2} \pm \mathrm{GnRH}$-induced changes in human $\alpha$-LUC activity in pituitary cells from transgenic mice (Colin et al. 1996).

Androgens, like estrogens, suppress $\alpha$ subunit expression either by reducing hypothalamic GnRH or by direct action on the pituitary. In vivo, testosterone suppressed $\alpha$ mRNA and mRNA synthesis rates in male rats even in the presence of GnRH antagonist (Paul et al. 1990). Similarly, testosterone or dihydrotestosterone (DHT) suppressed the post-CAST increases in $\alpha$ promoter activity in transgenic mice harboring either a human or bovine $\alpha$ promoter-CAT reporter gene
(Clay et al. 1993). The human $\alpha$-CAT reporter gene was also repressed by DHT when transiently transfected into $\alpha \mathrm{T} 3$ cells along with androgen receptor (AR), with suppression requiring both $\mathrm{AR}$ and ligand (Clay et al. 1993). A putative androgen response element (ARE) has been identified in the proximal promoter of the human $\alpha$ gene between tandem cAMP response elements (CRE) and a CGAAT element (Glay et al. 1993). However, this binding site does not mediate the suppressive effect of androgen on $\alpha$ transcription; instead, AR interferes with the proteins that bind an upstream $\alpha$-basal element and the CRE (Heckert et al. 1997). Specifically, AR suppresses $\alpha$ promoter activity by protein-protein interactions with the two CREbinding transcription factors cJun and ATF2 (Jorgensen \& Nilson 2001a).

The effects of glucocorticoids on $\alpha$ gene expression are inconclusive. In vivo, corticosterone (B) either increases (Ringstrom et al. 1991), decreases (Kilen et al. 1996), or had no effect (McAndrews et al. 1994) on a subunit mRNA in rats. In pituitary-derived cell lines, dexamethasone suppressed $\alpha$-subunit mRNA in $\alpha \mathrm{T} 3$ cells (Akerblom et al. 1990), had no effect on $\alpha$ mRNA in LßT2 cells (Turgeon et al. 1996) or increased $\alpha$ promoter activity in GH3 cells transiently transfected with a human $\alpha$-CAT construct (Gurr \& Kourides 1989).

\section{LH $\beta$}

Estrogens rapidly suppress the post-OVX increases in LH $\beta$ mRNA synthesis (Shupnik et al. 1988). This reflects a hypothalamic action, as the post-OVX increases in LH $\beta$ transcription were abolished by a GnRH antagonist (Dalkin et al. 1993, Shupnik \& Fallest 1994, Fallest et al. 1995, Burger et al. 2001), and additional treatment with $\mathrm{E}_{2}$ was no more effective than antagonist only (Shupnik \& Fallest 1994). However, estrogens also exert direct action on the pituitary, and $\mathrm{E}_{2}$ rapidly increased $\mathrm{LH} \beta$ mRNA synthesis rates in pituitary cells from OVX female rats (Shupnik et al. 1989a, Shupnik 1996), and in pituitary cells from cycling rats, with the greatest effect in cells from rats in proestrus (Shupnik et al. 1989a). Shupnik and coworkers found that ER bound the rat $\mathrm{LH} \beta$ promoter at -1388 to $-1105 \mathrm{bp}$, an area containing a $15 \mathrm{bp}$ imperfect ERE; moreover, promoter-reporter constructs of the rat LH $\beta$ gene containing the $284 \mathrm{bp}$ 
estrogen-responsive region, transiently transfected into GH3 cells, were estrogen responsive in an ER-dependent manner (Shupnik et al. 1989b, Shupnik \& Rosenzweig 1991). However, the estrogen responsiveness of the LH $\beta$ promoter may not be conserved across the species. While $\mathrm{E}_{2}$ suppressed LH $\beta$ promoter activity in OVX transgenic mice harboring a -776 to $+10 \mathrm{bp}$ bovine LH $\beta$ promoter CAT reporter, a highaffinity binding site for the ER was not found in this portion of the promoter (Keri et al. 1994). In addition, $\mathrm{E}_{2}$ had no effect on bovine LH $\beta$ CAT activity when transiently transfected into L $\beta$ T2 cells, even when cotransfected with the human ER (Jorgensen \& Nilson 2001b). It remains to be determined whether an estrogen-responsive region of the bovine LH $\beta$ promoter may be more $5^{\prime}$ than the area previously investigated. Alternatively, the ER may modulate promoter activity by interacting with other cis-acting elements, as described for androgens on the $\alpha$ and LH $\beta$ promoters.

There is little information on the regulation of LH $\beta$ gene expression by either $\mathrm{P}_{4}$ or glucocorticoids. Progesterone alone had no effect on LH $\beta$ mRNA levels in OVX rats and when combined with $\mathrm{E}_{2}$ was no more effective than $\mathrm{E}_{2}$ alone (Dalkin et al. 1990, Kerrigan et al. 1993). Similarly, while $\mathrm{E}_{2}$ blocked bovine LH $\beta$ CAT promoter activity in OVX transgenic mice, the combination of $\mathrm{E}_{2}$ and $\mathrm{P}_{4}$ was no more effective than $\mathrm{E}_{2}$ alone (McNeilly et al. 1996). In vitro, neither $\mathrm{P}_{4}$ nor $\mathrm{E}_{2}+\mathrm{P}_{4}$ altered LH $\beta$ mRNA levels in female rat pituitary cells, but $\mathrm{P}_{4}$ alone or in combination with $\mathrm{E}_{2}$ augmented the $\mathrm{GnRH}$-induced increase in LH $\beta$ mRNA, perhaps by blocking LH $\beta$ mRNA degradation (Park et al. 1996). Glucocorticoids do not appear to regulate LH $\beta$ mRNA; B had no effect on LH $\beta$ mRNA levels in cultured rat pituitary cells (Kilen et al. 1996) and dexamethasone did not alter the activity of the rat LH $\beta$ promoter (Shupnik \& Rosenzweig 1991).

Androgens rapidly suppress the post-CAST rise in LH $\beta$ transcription. Testosterone inhibited LH $\beta$ mRNA synthesis in CAST rats (Paul et al. 1990) and suppressed the post-CAST increases in LH $\beta$ promoter activity in transgenic mice (Keri et al. 1994, Fallest et al. 1995). We examined the effects of testosterone on LH $\beta$ transcription in vivo; testosterone rapidly suppressed LH $\beta$ PT below basal values in GnRH-deficient CAST rats (Fig. 11) (Burger et al. 2004). The suppression of LH $\beta$ PT in GnRH-deficient rats in vivo suggests that testosterone acts directly at the pituitary, but we found no effect of testosterone on LH $\beta$ PT in cultured rat pituitary cells (Burger et al. 2004). Similarly, DHT had little effect on rat LH $\beta$ promoter LUG reporter activity in L $\beta$ T2 cells, but did suppress GnRH-induced LH $\beta$ promoter activity (Curtin et al. 2001). This action required the AR even though a high-affinity binding site for the AR was not found in this construct. Curtin et al. (2001) determined that the AR suppressed rat LH $\beta$ promoter activity by protein-protein interactions with the specificity protein-1 (Spl) transcription factor, and, to a lesser extent, with the early growth response protein (Erg-1), which are required for GnRH stimulation of LH $\beta$ transcription (Kaiser et al. 2000, Weck et al. 2000). In contrast to the rat, the bovine LH $\beta$ promoter was directly responsive to testosterone (Jorgensen \& Nilson 2001b). The $\mathrm{AR}$, in a ligand-dependent manner, suppressed the activity of bovine LH $\beta$ CAT when transfected into L $\beta$ T2 cells. The bovine LH $\beta$ promoter also lacks an AR binding site, and the AR suppressed bovine LH $\beta$ transcription by protein-protein interactions with steriodogenic factor 1 (SF-1), blocking its interaction with Pitxl and the transcriptional initiation complex (Jorgenson \& Nilson 2001b).

\section{FSH $\beta$}

The effects of $\mathrm{E}_{2}$ on FSH $\beta$ transcription have not been extensively studied, and there appear to be differences among species. In vivo, $\mathrm{E}_{2}$ suppressed the post-OVX increase in FSH $\beta$ mRNA synthesis in the rat (Shupnik et al. 1988). The site of $\mathrm{E}_{2}$ action in the rat is the hypothalamus, as $\mathrm{E}_{2}$ did not suppress FSH $\beta$ transcription in OVX rats treated with a GnRH antagonist (Shupnik et al. 1989a) and had no effect on FSH $\beta$ mRNA synthesis in female rat pituitary fragments (Shupnik \& Fallest 1994). In contrast to the rat, $\mathrm{E}_{2}$ suppressed both steady-state FSH $\beta$ mRNA and mRNA synthesis rates in cultured ovine pituitary cells (Phillips et al. 1988, Baratta et al. 2001), and suppressed the activity of an ovine FSH $\beta$ promoter-LUG construct transfected into ovine pituitary cells (Miller \& Miller 1996). The estrogen-responsive region of the ovine FSH $\beta$ promoter is located at -105 to $-84 \mathrm{bp}$, but does not contain an estrogen-response element or bind ER (Miller \& Miller 1996). Instead, this estrogen-responsive region contains two AP-1 sites 

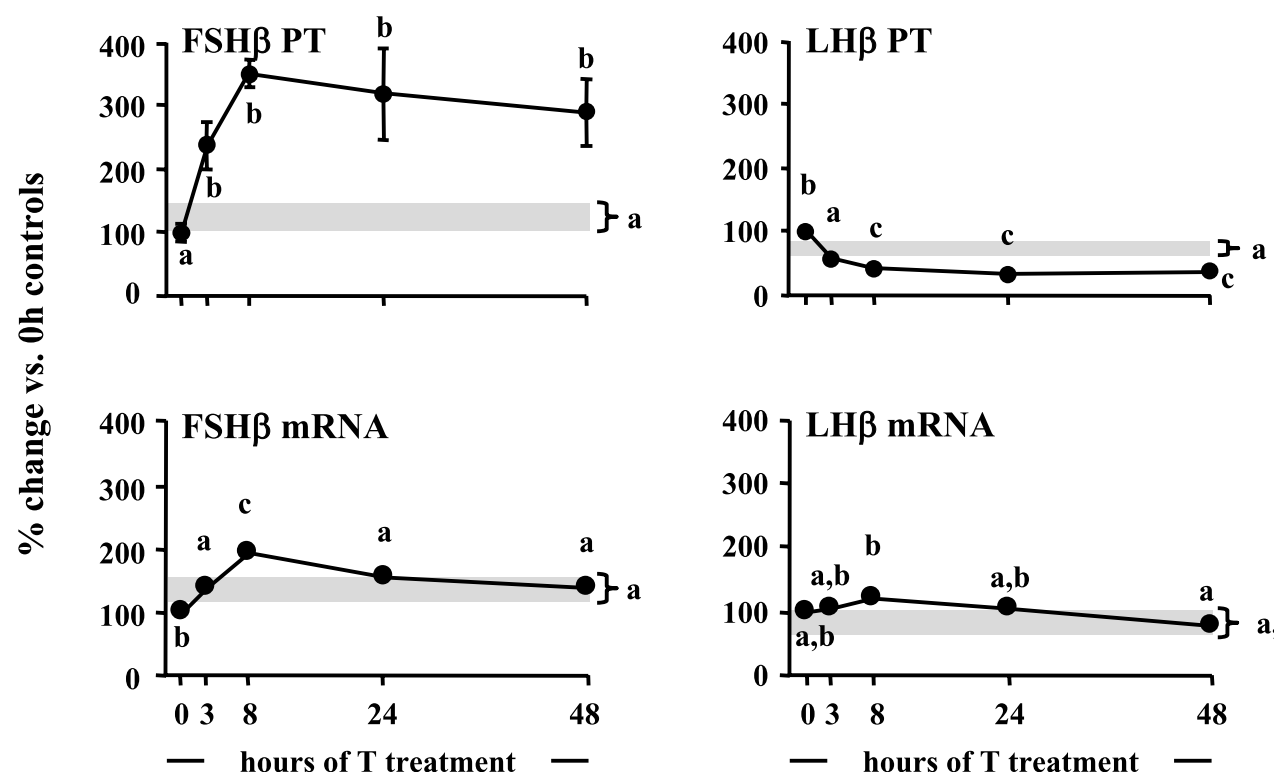

Figure 11 The time course of testosterone $(T)$ action on pituitary $\beta$-subunit primary transcripts (PT) and mRNAs in GnRH antagonist (GnRH-A)-treated CAST male rats. Castrated rats ( $n=4-7 /$ group) were treated with GnRH-A LRF-147 (100 $\mu$ g, s.c.) every $12 \mathrm{~h}$. Four days after CAST, rats received T implants and were killed $0,3,8,24$ and 48 later. All data are presented as percent 0-h T ( \pm S.E.) controls. Intact rat $( \pm$ S.E.) control values are represented by shading. Points with different letters are significantly different $(P<0.05)$.

and is a GnRH enhancer region of the ovine FSH $\beta$ promoter (Strahl et al. 1998). Although $\mathrm{E}_{2}$ inhibits FSH $\beta$ transcription in sheep, it had no effect on an ovine FSH $\beta$ promoter-LUG construct in female transgenic mice, and the authors suggest that mouse gonadotropes lack some factor making them less responsive to negative feedback by estrogen (Huang et al. 2001a). We recently investigated the effects of steroids on FSH $\beta$ transcription in male rats. Contrary to previous results in females, we found that $\mathrm{E}_{2}$ markedly suppressed FSH $\beta$ PT, but not $\mathrm{FSH} \beta$ mRNA, and this may suggest that $\mathrm{E}_{2}$ differentially regulates $\mathrm{FSH} \beta$ transcription between the sexes in rodents (Burger et al. 2004).

FSH $\beta$ transcription is also regulated by $\mathrm{P}_{4}$, and, like estrogens, there appear to be differences between species. Progesterone, in combination with $\mathrm{E}_{2}$, increased $\mathrm{FSH} \beta$ mRNA expression in immature rats (Attardi et al. 1990) and increased the stimulatory effects of GnRH on FSH $\beta$ mRNA (versus $\mathrm{E}_{2}$ alone) (Kerrigan et al. 1993). Moreover, the preovulatory FSH surge and the accompanying increase in FSH $\beta$ mRNA can be suppressed by antiprogestins (Ringstrom et al. 1997). Three progesterone-response element
(PRE)-like sequences have been identified in the proximal promoter of the rat FSH $\beta$ gene; these sites bind $\mathrm{P}_{4}$ receptor $(\mathrm{PR})$ and render a heterologous promoter-reporter construct $\mathrm{P}_{4}$ responsive (O'Conner et al. 1997, 1999). In contrast, $\mathrm{P}_{4}$ suppressed endogenous FSH $\beta$ mRNA synthesis in ovine pituitary cell cultures (Phillips et al. 1988). The ovine FSH $\beta$ promoter contains six PRE-like sequences that bind PR and render a heterologous promoter reporter construct $\mathrm{P}_{4}$ responsive (Webster et al. 1995). However, contrary to the suppressive effects of $\mathrm{P}_{4}$ on endogenous FSH $\beta$ transcription, $\mathrm{P}_{4}$ stimulated an ovine FSH $\beta$ promoter-LUG reporter construct transfected into ovine pituitary cells (Webster et al. 1995).

Glucocorticoids affect FSH $\beta$ gene expression, and B selectively upregulated FSH $\beta$ mRNA levels (Ringstrom et al. 1991, McAndrews et al. 1994). These effects are at the level of the gonadotrope, as $\mathrm{B}$ or dexamethasone increased FSH $\beta$ mRNA in rat pituitary cells (Kilen et al. 1996, Bohnsack et al. 2000, Leal et al. 2003) and in rats treated with a GnRH antagonist (McAndrews et al. 1994). Moreover, the effects of $\mathrm{B}$ appear to be at the level of transcription, as it increased FSH $\beta$ mRNA in 
female rat pituitary cells, without changing post-transcriptional mRNA decay rates (Kilen et al. 1996).

The effects of testosterone on FSH $\beta$ gene expression in the rat are intriguing. As mentioned previously, testosterone does not suppress the post-GDX increase in FSH $\beta$ mRNA; instead, it either has no effect or further increases $\mathrm{FSH} \beta$ mRNA expression (Gharib et al. 1987, 1990a, Wierman et al. 1988, 1990, Iliff-Sizemore et al. 1990). Studies in GnRH-deficient rats or in pituitary cell cultures demonstrated that the stimulatory effects of testosterone on FSH $\beta$ gene expression are at the level of the pituitary (Paul et al. 1990, Wierman \& Wang 1990, Dalkin et al. 1992, Winters et al. 1992). Earlier we proposed that testosterone regulated FSH $\beta$ mRNA stability, since testosterone increased the half-disappearance time of FSH $\beta$ mRNA from 20 to $50 \mathrm{~h}$, but did not significantly increase FSH $\beta$ mRNA synthesis (Paul et al. 1990). However, we recently reinvestigated the effects of testosterone on FSH $\beta$ transcription, and found that it rapidly and specifically increases FSH $\beta$ PT levels at 3-48 h in male rats (Fig. 11) and that the stimulatory effects on FSH $\beta$ transcription are androgen specific (Burger et al. 2004). Testosterone also suppresses FS mRNA, which suggests that testosterone's actions on FSH $\beta$ transcription may be indirect via activin/FS. Others have reported that the effects of testosterone on FSH $\beta$ mRNA either require activin (Leal et al. 2003) or are blunted by FS (Bohnsack et al. 2000). To determine whether testosterone stimulation of FSH $\beta$ PT reflected the fall in pituitary FS, we treated male rat pituitary cells with testosterone with or without exogenous FS. FS alone suppressed FSH $\beta$ PT, but did not reduce the testosteronestimulated increase in FSH $\beta$ PT, suggesting that testosterone increases transcription by direct action on the FSH $\beta$ gene. Recently, testosterone (or DHT) was reported to increase the activity of an ovine FSH $\beta$ promoter-reporter transfected into LßT2 cells (Spady et al. 2004). Spady et al. (2004) identified three candidate androgen-response elements (AREs) at $-245 /-231,-212 /-198$ and $-153 /-139$ bp of the ovine FSH $\beta$ promoter, which are the same steroid-binding elements identified by Webster et al. (1995) as PREs. Only the $-245 /-231 \mathrm{bp}$ putative ARE bound the AR, although mutations in either the $-245 /-231$ or $-153 /-139$ ARE disrupted the stimulation of the promoter by DHT (Spady et al. 2004). In contrast to the rat, the effects of testosterone on the ovine FSH $\beta$ promoter are activin dependent. The ability of DHT to stimulate the ovine FSH $\beta$ promoter is abolished by FS treatment, is increased synergistically by activin, and requires an activin-responsive Smad-binding element (SBE) at -138/-124 bp (Spady et al. 2004). Although the AREs identified in the ovine FSH $\beta$ promoter are well conserved across mammalian species (Spady et al. 2004), the stimulatory effects of testosterone on FSH $\beta$ expression are not. Testosterone suppressed FSH $\beta$ mRNA in male rhesus pituitary cells (Kawakami et al. 2002) and a human FSH $\beta$ promoter construct in transgenic mice (Kumar et al. 1992, Kumar \& Low 1993, 1995).

\section{Regulation of FSH $\beta$ gene transcription by activin, FS and inhibin}

Differential synthesis and secretion of LH and FSH, while in part dependent on the hypothalamic GnRH signal pattern, also appears to result from the actions of multiple local and gonadal peptide hormones. The hormones inhibin, activin and FS are produced both in the gonads and, at least for activin and FS, in the pituitary gland. Alterations in the balance of activin and inhibin concentrations, either directly or via changes in FS (for activin), selectively alter FSH secretion by regulating FSH $\beta$ gene expression (Mather et al. 1997).

The inhibins and activins are members of the transforming growth factor- $\beta$ (TGF $\beta$ ) superfamily. The inhibins, heterodimers of an inhibin $\alpha$-subunit and one of two $\beta$-subunits, $\beta_{\mathrm{A}}$ (inhibin $\mathrm{A}$ ) or $\beta_{\mathrm{B}}$ (inhibin $\mathrm{B}$ ), are produced primarily by the gonads and act in an endocrine manner to suppress pituitary FSH secretion without affecting LH (Burger et al. 1997). The activins are dimers of two inhibin $\beta$-subunits. There are at least four forms of the $\beta$ subunit, $\beta_{\mathrm{A}}-\beta_{\mathrm{D}}$, although the $\beta_{\mathrm{A}}$ and $\beta_{\mathrm{B}}$ subunits are important in the regulation of FSH. The activins were discovered because of their ability to stimulate FSH synthesis and release it from pituitary cell cultures (Ling et al. 1986, Vale et al. 1986), but it is now known that the activins are produced in a wide variety of tissues and act largely in a paracrine/autocrine manner to regulate functions ranging from development to cellular homeostasis. The pituitary expresses $\beta_{\mathrm{B}}$, and 
activin-B $\left(\beta_{\mathrm{B}} \beta_{\mathrm{B}}\right)$ is synthesized and secreted in the pituitary, whereas most other tissues produce activin-A (Meunier et al. 1988). In addition, the activin receptors types I, IIA and IIB are also present in the rat pituitary (Dalkin et al. 1996). FS, a glycoprotein hormone structurally unrelated to the activins and inhibins, binds to and neutralizes the bioactivity of activin. The affinity of FS for activin is high, and the dissociation rate after binding is extremely slow, essentially making the binding event a permanent one (Nakamura et al. 1990). FS was discovered in ovarian follicular fluid by its ability to suppress FSH (Esch et al. 1987), but, like activin, it is also synthesized in a wide array of tissues, including the pituitary gonadotropes and folliculostellate cells (Kogawa et al. 1991a,b, Kaiser et al. 1992). Although FS can be detected in the circulation, its ability to suppress FSH is largely due to paracrine and/or autocrine regulation of bioactive activin at the level of the gonadotrope (for review, see Phillips \& de Kretser 1998).

Activin is an important regulator of FSH secretion and FSH $\beta$ gene expression; it increased FSH secretion and FSH $\beta$ mRNA in a dosedependent manner in primary rat pituitary cells (Carroll et al. 1989, Weiss et al. 1993), and increased FSH secretion in vivo (Rivier \& Vale 1991, Carrol et al. 1991, Woodruff et al. 1993, Lee \& Rivier 1997). The intrapituitary regulation of activin action is important in control of FSH $\beta$ gene expression; after OVX, pituitary $\beta_{\mathrm{B}}$ and ActRII mRNAs increase in parallel with FSH $\beta$ mRNA (Dalkin et al. 1994, 1998, Prendergast et al. 2004), and GnRH pulse frequencies that maximally stimulate $\mathrm{FSH} \beta$ mRNA also stimulate $\beta_{\mathrm{B}}$ mRNA (Dalkin et al. 1999). Activin increases FSH $\beta$ mRNA expression by increasing transcription. Activin increased FSH $\beta$ PT in rat pituitary cells, an effect which could be blocked by the transcription inhibitor actinomycin D (Weiss et al. 1995, Bernard 2004). Activin has also been reported to stimulate ovine, rat and mouse FSH $\beta$ promoter-reporter constructs (Huang et al. 2001b, Pernasetti et al. 2001, Dupont et al. 2003, Suszko et al. 2003, Bailey et al. 2004, Bernard 2004). In light of these data, recent studies have begun to focus on the mechanism(s) whereby activin signaling regulates promoter activity for the FSH $\beta$ gene.

Activin signaling requires a series of events, including the activation of intracellular messengers (for review, see Attisano \& Wrana 1996, Pangus \&
Woodruff 2000, Derynck \& Zhang 2003). Briefly, activin binds to its type II receptor subunit, either ActRII or IIB, which then pairs with a type I receptor subunit (either ActRI or IB), forming a heteromeric complex at the cell surface. Then serine/threonine kinase activity of the type II subunit phosphorylates the type I subunit, initiating post-receptor signaling/phosphorylation. Although a number of signal cascades may be activated as the result of activin/activin receptor association, the predominant activin-signaling pathway includes the mothers against dpp-related (Smad) proteins.

Eight Smad proteins (Smads 1-8) conduct the intracellular signals for the TGF $\beta$ super family from receptors to the nucleus (for review, see Derynck \& Zhang 2003). For the activin signaling system, receptor-activated Smads2 and 3 are phosphorylated by ActRI and then partner with co-Smad4, which then binds to DNA to regulate gene activity. In pituitary cells, activin-induced increases in FSH $\beta$ transcription were correlated with increased Smad2 and 3 phosphorylation (Dupont et al. 2003, Bernhard 2004). Additionally, rat or mouse FSH $\beta$ promoter activity was increased by overexpression of Smad3 and attenuated when Smad2 or 3 protein were suppressed (Dupont et al. 2003, Suszko et al. 2003, Bernhard 2004).

The association of Smad2/3 with Smad4 and the formation of dimers is an important step in signal transduction from the cell surface (Lagna et al. 1996). Smad4 appears essential for activin signaling, as transfection of a constitutively active Smad4 construct alone can induce activin-like effects, whereas cellular expression of Smad2/3 alone does not confer responsiveness (Lagna et al. 1996), and in pituitary cells expression of Smad4 greatly enhances the ability of Smad3 to increase rat FSH $\beta$ promoter activity (Suszko et al. 2003). Additionally, Smad2/3 activity is regulated by 'inhibitory' Smad7, which binds the type I receptor and prevents Smad2/3 phosphorylation. Smad7 gene expression is detected in both normal pituitary cells and gonadotrope cell lines, and overexpression of Smad7 in LBT2 cells disrupted activin-induced increases in FSH $\beta$ gene expression (Dupont et al. 2003, Bernhard 2004).

To date, data suggest that there is a Smadbinding element (SBE) comprising CAGA- or GTCT-like sequences that are required, but are not sufficient, for Smad binding (Shi \& Massague 2003). The affinity of Smads for SBEs is low, and 
gene activation requires the presence of other cofactors. Some of these transcriptional regulators are specific to the FSH $\beta$ gene, as recent reports suggest the importance of the nuclear factor Pitx2, a member of the Pitx subfamily of bicoid-related homeodomain factors (Suszko et al. 2003). In that report, critical regions within the rat $\mathrm{FSH} \beta$ promoter were identified for $\operatorname{Smad} 3 / 4$ binding $(-281$ to $-253 \mathrm{bp})$ and Pitx2 (-230 to $-199 \mathrm{bp})$; more importantly, both Smads and Pitx2 may physically interact in the regulation of the FSH $\beta$ promoter activation. However, the critical SBE in the rat promoter is conserved only in rodent species. In the ovine FSH $\beta$ promoter, there are three regions $(-973 /-962,-167$ and -134$)$ required for full activin responsiveness (Bailey et al. 2004). The distal -973/-962 site bound Smad4 protein, and the critical -134 site bound Smad4 in association with the TALE homeodomain proteins Pbxl and Prepl, and the two proximal activin responsive regions $(-167$ and -134$)$ are conserved across species and also bind Pbxl and Prepl in the mouse gene (Bailey et al. 2004).

Limitation of activin action appears to be an essential component of physiologic gonadotrope function. In addition to the intracellular inhibitor Smad7 described above, the extracellular inhibitors FS and inhibin play key roles in limiting activin action. In the rat pituitary, FS is upregulated by activin, GnRH and PACAP, and is suppressed by testosterone and by FS itself, probably through binding to activin (Simonaka et al. 1991, Kirk et al. 1994, Winters et al. 1997, Burger et al. 2003, 2004). Conversely, in primate pituitary cultures, GnRH is ineffective, and testosterone (as well as activin) increases FS expression (Kawakami et al. 2002). Current thoughts regarding the physiologic role of pituitary-derived FS remain speculative, as a FS-deficient cell model is lacking and knockout of the FS gene is lethal (Matzuk et al. 1995). However, it is widely regarded that pituitary FS influences the FSH response to hypothalamic and gonadal stimuli. FS expression increases after CAST in adult male rats (Kaiser \& Chin 1993) and during the reproductive cycle (Halvorson et al. 1994). Additionally, there is a reciprocal relationship over time between FS and FSH $\beta$ transcription after GnRH pulses; fast-frequency GnRH pulses stimulated FSH $\beta$ only transiently, and this was followed by an increase in FS mRNA, whereas slowfrequency pulses suppressed FS and increased
FSH $\beta$, implying that FS attenuates the FSH response (Burger et al. 2002). In male primates, by contrast, FS mRNA is unaffected by CAST, and FSH $\beta$ mRNA increases by about 50 -fold (Winters et al. 2001). Thus, FS appears to function as a brake on FSH production in rodents, but its role in other mammalian species is less certain.

Circulating inhibin is also important in antagonizing the action of activin on pituitary FSH. Serum inhibin levels in the rat are regulated across the estrous cycle and are greatest early in the cycle, peaking at proestrus and declining to their lowest levels at estrus. Low inhibin levels at estrus are coincident with increased FSH secretion, steadystate FSH $\beta$ mRNA, and FSH $\beta$ transcription associated with the secondary FSH surge (Shupnik et al. 1989a, Haisenleder et al. 1990, Woodruff et al. 1996). As mentioned previously, after OVX and the loss of circulating inhibin, there is a rapid and GnRH-independent increase in both FSH $\beta$ mRNA and FSH $\beta$ PT, which can be mimicked by giving inhibin- $\alpha$ antisera to intact rats (Burger et al. 2001). Inhibin administration also decreased ovine FSH $\beta$ promoter-LUG activity in pituitary cells from transgenic mice and rapidly suppressed FSH $\beta$ transcription in OVX rats and ewes (Burger et al. 2001, Huang et al. 2001a, Clarke et al. 1993). In addition to suppressing FSH $\beta$ transcription, inhibin may also regulate the stability of the FSH $\beta$ mRNA. In rats, inhibin suppressed FSH $\beta$ mRNA levels with a half-life of $94 \mathrm{~min}$, much shorter than the 40-h half-life of FSH $\beta$ mRNA in vivo (Burger et al. 2001). In sheep, inhibin suppressed FSH $\beta$ transcription by only $50 \%$ but mRNA levels by $100 \%$ (Clarke et al. 1993). Suppression of FSH $\beta$ mRNA by inhibin in rat pituitary cells could also be blunted by inhibitors of translation, suggesting that inhibin stimulates transcription of a protein that reduces FSH $\beta$ mRNA stability (Attardi et al. 1991, Attardi \& Winters 1993).

The mechanism for the effects of inhibin on FSH $\beta$ transcription are not clear; the inhibins do bind the activin type II receptors, although with much lower affinity than activin, but this binding does not promote association with the type I receptor, initiate intracellular Smad signaling, or appear to have its own signaling pathway (Mathews \& Vale 1991, Attisano et al. 1992, dePaolo 1997), suggesting that inhibin may work as a functional antagonist for activin at the level of the activin receptor. However, in view of inhibin's low affinity 
for the type II receptors, this does not explain inhibin action even in the presence of excess activin. Recently, two potential receptors/coreceptors for inhibin have been identified: betaglycan and inhibin-binding protein/p120 (InhBP/p120) (Chong et al. 2000, Lewis et al. 2000). However, new data suggest that betaglycan may be of greater physiologic importance (Chapman et al. 2002). Transfection of COS-7 or HEK293 cells with an expression vector encoding the full-length InhBP/ p120 cDNA (alone or in addition to either of the type II activin receptors) failed to induce specific inhibin binding. In contrast, transfection with constructs containing full-length betaglycan conferred high-affinity inhibin binding with formation of an inhibin/betaglycan/type II activin receptor complex. Furthermore, betaglycan immunoreactivity localizes with gonadotrope cells in the pituitaries of both male and female rats and is correlated with high-serum inhibin, low-serum FSH, and lowpituitary FSH $\beta$ immunoreactivity just before and after the FSH surge in cycling rats (MacConell et al. 2002, Chapman \& Woodruff 2003).

\section{Acknowledgements}

This work was supported by National Institutes of Health (NIH) grants HD11489 and HD33039 (to J C M), by postdoctoral fellowship F32 HD08572 (to L L B), and by the Core Laboratories of Specialized Collaborative Centers Program for Research in Reproduction Center grant U54 HD28934.

\section{References}

Akerblom IE, Ridgway EC \& Mellon PL 1990 An alpha-subunitsecreting cell line derived from a mouse thyrotrope tumor. Molecular Endocrinology 4 589-596.

Ando H, Hew CL \& Urano A 2001 Signal transduction pathways and transcription factors involved in the gonadotropin-releasing hormone-stimulated gonadotropin subunit gene expression. Comparative Biochemistry and Physiology. Part B, Biochemistry and Molecular Biology 129 525-532.

Andrews WV \& Conn PM 1986 GnRH stimulates mass changes in phosphoinositides and diacylglycerol accumulation in purified gonadotrope cell cultures. Endocrinology 118 1148-1153.

Attardi B \& Fitzgerald T 1990 Effects of progesterone on the estradiol-induced follicle-stimulating hormone (FSH) surge and FSH beta messenger ribonucleic acid in the rat. Endocrinology 126 2281-2287.

Attardi B \& Winters SJ 1993 Decay of follicle-stimulating hormone-beta messenger RNA in the presence of transcriptional inhibitors and/or inhibin, activin, or follistatin. Molecular Endocrinology 7 668-680.
Attardi B, Keeping HS, Winters SJ, Kotsuji F \& Troen P 1991 Comparison of the effects of cycloheximide and inhibin on the gonadotropin subunit messenger ribonucleic acids. Endocrinology $128 \quad 119-125$.

Attisano L \& Wrana JL 1996 Signal transduction by members of the transforming growth factor- $\beta$ superfamily. Cytokine and Growth Factor Revierws 7 327-339.

Bäckström CT, McNeilly AC, Leask RM \& Baird DT 1982 Pulsatile secretion of $\mathrm{LH}, \mathrm{FSH}$, prolactin, oestradiol and progesterone during the human menstrual cycle. Clinical Endocrinology (Oxford) $\mathbf{1 7}$ 29-42.

Bailey JS, Rave-Harel N, McGillivray SM, Coss D \& Mellon PL 2004 Activin regulation of the follicle-stimulating hormone $\beta$-subunit gene involves Smads and the TALE homeodomain proteins Pbxl and Prep1. Molecular Endocrinology 18 1158-1170.

Baratta M, West LA, Turzillo AM \& Nett TM 2001 Activin modulates differential effects of estradiol on synthesis and secretion of follicle-stimulating hormone in ovine pituitary cells. Biology of Reproduction 64 714-719.

Bedecarrats GY \& Kaiser UB 2003 Differential regulation of gonadotropin subunit gene promoter activity by pulsatile gonadotropin-releasing hormone $(\mathrm{GnRH})$ in perifused L $\beta \mathrm{T} 2$ cells: role of GnRH receptor concentration. Endocrinology 144 1802-1811.

Ben Menahem D \& Naor Z 1994 Regulation of gonadotropin mRNA levels in cultured rat pituitary cells by gonadotropin-releasing hormone $(\mathrm{GnRH})$ : role for $\mathrm{Ca}^{2+}$ and protein kinase C. Biochemistry 33 3698-3704.

Bernard DJ 2004 Both SMAD2 and SMAD3 Mediate activin-stimulated expression of the follicle-stimulating hormone $\beta$ subunit in mouse gonadotrope cells. Molecular Endocrinology 18 606-623.

Bilezikjian LM, Corrigan AZ, Blount AL, Chen Y \& Vale WW 2001 Regulation and actions of Smad7 in the modulation of activin, inhibin, and transforming growth factor-beta signaling in anterior pituitary cells. Endocrinology 142 1065-1072.

Bohnsack BL, Szabo M, Kilen SM, Tam DH \& Schwartz NB 2000 Follistatin suppresses steroid-enhanced follicle-stimulating hormone release in vitro in rats. Biology of Reproduction 62 636-641.

Bourne GA 1988 cAMP indirectly mediates the extracellular calcium independent release of LH. Molecular and Cellular Endocrinology $\mathbf{5 8}$ 155-160.

Burger HG \& Robertson DM 1997 Editorial: inhibin in the male progress at last. Endocrinology 138 1361-1362.

Burger LL, Dalkin AC, Aylor KW, Workman LJ, Haisenleder DJ \& Marshall JC 2001 Regulation of gonadotropin subunit

transcription after ovariectomy in the rat: measurement of subunit primary transcripts reveals differential roles of GnRH and inhibin. Endocrinology 142 3435-3442.

Burger LL, Dalkin AC, Aylor KW, Haisenleder DJ \& Marshall JC $2002 \mathrm{GnRH}$ pulse frequency modulation of gonadotropin subunit gene transcription in normal gonadotropes - assessment by primary transcript assay provides evidence for roles of $\mathrm{GnRH}$ and follistatin. Endocrinology 143 3243-3249.

Burger LL, Haisenleder DJ, Aylor KW, Dalkin AC, Prendergast KA \& Marshall JC 2004 Regulation of luteinizing hormone- $\beta$ and follicle-stimulating hormone (FSH)- $\beta$ gene transcription by androgens: testosterone directly stimulates FSH- $\beta$ transcription independent from its role on follistatin gene expression. Endocrinology 145 71-78.

Carroll RS, Corrigan AZ, Gharib SD, Vale W \& Chin WW 1989 Inhibin, activin, and follistatin: regulation of follicle-stimulating hormone messenger ribonucleic acid levels. Molecular Endocrinology 3 1969-1976.

Carroll RS, Kowash PM, Lofgren JA, Schwall RH \& Chin WW 1991 In vivo regulation of FSH synthesis by inhibin and activin. Endocrinology 129 3299-3304. 
Chapman SG \& Woodruff TK 2003 Betaglycan localization in the female rat pituitary: implications for the regulation of follicle-stimulating hormone by inhibin. Endocrinology 144 5640-5649.

Chapman SC, Bernard DJ, Jelen J \& Woodruff TK 2002 Properties of inhibin binding to betaglycan, InhBP/p120 and the activin type II receptors. Molecular and Cellular Endocrinology 196 79-93.

Chen X, Rubock MJ \& Whitman M 1996 A transcriptional partner for MAD proteins in TGF- $\beta$ signaling. Nature 383 691-696.

Chen Y, Bhushan A \& Vale W 1997 Smad 8 mediates the signaling of the receptor serine kinase. PNAS 94 12938-12943.

Chin WW 1987 Glycoprotein hormone genes. In Genes Encoding Hormones and Regulated Peptides, pp 137-149. Ed. JF Habener. Clifton, NJ: Humana Press.

Chong H, Pangas SA, Bernard DJ, Wang E, Gitch J, Chen W, Draper LB, Cox ET \& Woodruff TK 2000 Structure and expression of a membrane component of the inhibin receptor system. Endocrinology 141 2600-2607.

Clarke IJ \& Cummins JT 1982 The temporal relationship between gonadotropin releasing hormone $(\mathrm{GnRH})$ and luteinizing hormone (LH) secretion in ovariectomized ewes. Endocrinology 111 $1737-1739$

Clarke IJ, Rao A, Fallest PC \& Shupnik MA 1993 Transcription rate of the follicle stimulating hormone (FSH) beta subunit gene is reduced by inhibin in sheep but this does not fully explain the decrease in mRNA. Molecular and Cellular Endocrinology 91 211-216.

Clay CM, Keri RA, Finicle AB, Heckert LL, Hamernik DL, Marschke KM, Wilson EM, French FS \& Nilson JH 1993 Transcriptional repression of the glycoprotein hormone alpha subunit gene by androgen may involve direct binding of androgen receptor to the proximal promoter. Fournal of Biological Chemistry 268 13556-13564.

Colin IM, Bauer-Dantoin AC, Sundaresan S, Kopp P \& Jameson JL 1996 Sexually dimorphic transcriptional responses to gonadotropin-releasing hormone require chronic in vivo exposure to estradiol. Endocrinology 137 2300-2307.

Cui ZJ, Gorelick FS \& Dannies PS 1994 Calcium/calmodulindependent protein kinase-II activation in rat pituitary cells in the presence of thyrotropin-releasing hormone and dopamine. Endocrinology 134 2245-2250.

Cui ZJ, Hidaka H \& Dannies PS 1996 KN-62, a calcium/ calmodulin-dependent protein kinase II inhibitor, inhibits high potassium-stimulated prolactin secretion and intracellular calcium increases in anterior pituitary cells. Biochimica et Biophysica Acta $1310343-347$.

Curtin D, Jenkins S, Farmer N, Anderson AC, Haisenleder DJ, Rissman E, Wilson EM \& Shupnik MA 2001 Androgen suppression of GnRH-stimulated rat LHbeta gene transcription occurs through $\mathrm{Spl}$ sites in the distal GnRH-responsive promoter region. Molecular Endocrinology 15 1906-1917.

Dalkin AC, Haisenleder DJ, Ortolano GA, Ellis TR \& Marshall JC 1989 The frequency of gonadotropin-releasing-hormone stimulation differentially regulates gonadotropin subunit messenger ribonucleic acid expression. Endocrinology 125 917-924.

Dalkin AC, Haisenleder DJ, Ortolano GA, Suhr A \& Marshall JC 1990 Gonadal regulation of gonadotropin subunit gene expression: evidence for regulation of follicle-stimulating hormone-beta messenger ribonucleic acid by nonsteroidal hormones in female rats. Endocrinology 127 798-806.

Dalkin AC, Paul SJ, Haisenleder DJ, Ortolano GA, Yasin M \& Marshall JC 1992 Gonadal steroids effect similar regulation of gonadotrophin subunit mRNA expression in both male and female rats. Fournal of Endocrinology 132 39-45.

Dalkin AC, Knight CD, Shupnik MA, Haisenleder DJ, Aloi J, Kirk SE, Yasin M \& Marshall JC 1993 Ovariectomy and inhibin immunoneutralization acutely increase follicle-stimulating hormone-beta messenger ribonucleic acid concentrations: evidence for a nontranscriptional mechanism. Endocrinology 132 1297-1304.

Dalkin AC, Haisenleder DJ, Yasin M, Gilrain JT \& Marshall JC 1996 Pituitary activin receptor subtypes and follistatin gene expression in female rats: differential regulation by activin and follistatin. Endocrinology 137 548-554.

Dalkin AC, Haisenleder DJ, Gilrain JT, Aylor K, Yasin M \& Marshall JC 1998 Regulation of pituitary follistatin and inhibin/activin subunit messenger ribonucleic acids (mRNAs) in male and female rats: evidence for inhibin regulation of follistatin mRNA in females. Endocrinology 139 2818-2823.

Dalkin AC, Haisenleder DJ, Gilrain JT, Aylor K, Yasin M \& Marshall JC 1999 Gonadotropin-releasing hormone regulation of gonadotropin subunit gene expression in female rats: actions on follicle-stimulating hormone beta messenger ribonucleic acid (mRNA) involve differential expression of pituitary activin (beta-B) and follistatin mRNAs. Endocrinology 140 903-908.

Dalkin AC, Burger LL, Aylor KW, Haisenleder DJ, Workman LJ, Cho S \& Marshall JC 2001 Regulation of gonadotropin subunit gene transcription by gonadotropin-releasing hormone: measurement of primary transcript ribonucleic acids by quantitative reverse transcription-polymerase chain reaction assays. Endocrinology 142 139-146.

De Koninck P \& Schulman H 1998 Sensitivity of CaM kinase II to the frequency of calcium oscillations. Science 279 227-230.

Delegeane AM, Ferland LH \& Mellon PL 1987 Tissue specific enhancer of human glycoprotein hormone alpha-subunit gene: dependence on cAMP-inducible elements. Molecular and Cellular Biology $73994-4002$.

DePaolo LV 1997 Inhibins, activins, and follistatins: the saga continues. Proceedings of the Society for Experimental Biology and Medicine 214 328-339.

Derynck R \& Zhang YE 2003 Smad-dependent and Smad-independent pathways in TGF-beta family signalling. Nature 425 577-584.

Di Gregorio GB \& Nett TM 1995 Estradiol and progesterone influence the synthesis of gonadotropins in the absence of gonadotropin-releasing hormone in the ewe. Biology of Reproduction 53 166-172.

Dolmetsch RE, Lewis RS, Goodnow CG \& Healy JI 1997 Differential activation of transcriptional factors induced by calcium response amplitude and duration. Nature 386 855-858.

Duan WR, Shin JL \& Jameson JL 1999 Estradiol suppresses phosphorylation of cAMP response element binding protein (CREB) in the pituitary: evidence for indirect action via $\mathrm{GnRH}$. Molecular Endocrinology 13 1338-1352.

Dupont J, McNeilly J, Vaiman A, Canepa S, Combarnous Y \& Taragnat C 2003 Activin signaling pathways in ovine pituitary and L $\beta$ T2 gonadotrope cells. Biology of Reproduction 68 1877-1887.

Durham PL \& Russo AF 2000 Differential regulation of MAPK-responsive genes by duration of a calcium signal. Molecular Endocrinology 14 1570-1582.

Ellsworth BS, White BR, Burns AT, Cherrington BD, Otis AM \& Clay CM 2003 c-Jun N-terminal kinase activation of activator protein-1 underlies homologous regulation of the gonadotropin-releasing hormone receptor gene in alpha T3-1 cells. Endocrinology 144 839-849.

Esch FS, Shimasaki S, Mercado M, Cooksey K, Ling N, Ying S, Ueno N \& Guillemin R 1987 Structural characterization of follistatin: a novel follicle-stimulating hormone release-inhibiting polypeptide from the gonad. Molecular Endocrinology 1 849-855.

Fallest PC, Trader GL, Darrow JM \& Shupnik MA 1995 Regulation of rat luteinizing hormone beta gene expression in transgenic mice by steroids and a gonadotropin-releasing hormone antagonist. Biology of Reproduction 53 103-109.

Fowkes RC, King P \& Burrin JM 2002 Regulation of human glycoprotein hormone alpha-subunit gene transcription in 
L $\beta$ T2 gonadotropes by protein kinase $\mathrm{C}$ and extracellular signal-regulated kinase 1/2. Biology of Reproduction 67 725-734.

Garrel G, McArdle CA, Hemmings BA \& Counis R 1997 Gonadotropin-releasing hormone and pituitary adenylate cyclase-activating polypeptide affect levels of cyclic adenosine $3^{\prime}, 5^{\prime}$ - monophosphate-dependent protein kinase A (PKA) subunits in the clonal gonadotrope alphaT3-1 cells: evidence for cross-talk between PKA and protein kinase C pathways. Endocrinology 138 2259-2266.

Gharib SD, Wierman ME, Badger TM \& Chin WW 1987 Sex steroid hormone regulation of follicle-stimulating hormone subunit messenger ribonucleic acid (mRNA) levels in the rat. Fournal of Clinical Investigation 80 294-299.

Gharib SD, Leung PC, Carroll RS \& Chin WW 1990a Androgens positively regulate follicle-stimulating hormone beta-subunit mRNA levels in rat pituitary cells. Molecular Endocrinology 4 1620-1626.

Gharib SD, Wierman ME, Shupnik MA \& Chin WW 1990 b Molecular biology of the pituitary gonadotropins. Endocrine Reviews 11 177-199.

Gu X \& Spitzer NC 1995 Distinct aspects of neuronal differentiation encoded by frequency of spontaneous calcium transients. Nature $375784-787$.

Gurr JA \& Kourides IA 1989 Regulation of the transfected human glycoprotein hormone alpha-subunit gene by dexamethasone and thyroid hormone. DNA 8 473-480.

Hahn SA, Schutte M, Hoque AT, Moskaluk CA, da Costa LT, Rozenblum E, Weinstein CL, Fischer A, Yeo CJ, Hruban RH \& Kern SE 1996 DPC4, a candidate tumor suppressor gene at human chromosome 18q21.1. Science 271 350-353.

Haisenleder DJ, Katt JA, Ortolano GA, el-Gewely MR, Duncan JA, Dee C \& Marshall JC 1988 Influence of gonadotropin-releasing hormone pulse amplitude, frequency, and treatment duration on the regulation of luteinizing hormone (LH) subunit messenger ribonucleic acids and LH secretion. Molecular Endocrinology $\mathbf{2}$ 338-343.

Haisenleder DJ, Ortolano GA, Jolly D, Dalkin AC, Landefeld TD \& Vale WW, Marshall JC 1990 Inhibin secretion during the rat estrous cycle: relationships to FSH secretion and FSH beta subunit mRNA concentrations. Life Sciences 47 1769-1773.

Haisenleder DJ, Dalkin AC, Ortolano GA, Marshall JC \& Shupnik MA 1991 A pulsatile gonadotropin-releasing hormone stimulus is required to increase transcription of the gonadotropin subunit genes: evidence for differential regulation of transcription by pulse frequency in vivo. Endocrinology 128 509-517.

Haisenleder DJ, Yasin M \& Marshall JC 1992 Enhanced effectiveness of pulsatile $3^{\prime}, 5^{\prime}$-cyclic adenosine monophosphate in stimulating prolactin and alpha-subunit gene expression. Endocrinology 131 3027-3033.

Haisenleder DJ, Ortolano GA, Yasin M, Dalkin AC \& Marshall JC $1993 a$ Regulation of gonadotropin subunit messenger ribonucleic acid expression by gonadotropin-releasing hormone pulse amplitude in vitro. Endocrinology 132 1292-1296.

Haisenleder DJ, Yasin M \& Marshall JC 1993b The regulation of prolactin, thyrotropin and gonadotropin subunit gene expression by pulsatile or continuous calcium signals. Endocrinology 133 2055-2061.

Haisenleder DJ, Yasin M \& Marshall JC 1995 Regulation of gonadotropin, thyrotropin subunit and prolactin mRNAs by pulsatile or continuous PKC stimulation. Endocrinology 136 13-19.

Haisenleder DJ, Yasin M \& Marshall JC 1997 Gonadotropin subunit and gonadotropin-releasing hormone receptor gene expression are regulated by alterations in the frequency of calcium pulsatile signals. Endocrinology 138 5227-5230.

Haisenleder DJ, Cox ME, Parsons SJ \& Marshall JC 1998 Gonadotropin-releasing hormone pulses are required to maintain activation of mitogen-activated protein kinase: role in stimulation of gonadotrope gene expression. Endocrinology 139 3104-3111.

Haisenleder DJ, Workman LJ, Burger LL, Aylor KW, Dalkin AC \& Marshall JC 2001 Gonadotropin subunit transcriptional responses to calcium signals in the rat: evidence for regulation by pulse frequency. Biology of Reproduction 65 1789-1793.

Haisenleder DJ, Burger LL, Aylor KW, Dalkin AC \& Marshall JC $2003 a \mathrm{GnRH}$ stimulation of gonadotropin subunit transcription: evidence for the involvement of calcium/calmodulin-dependent protein kinase type II (Ca/CAMK II) activation in rat pituitaries. Endocrinology 144 2768-2774.

Haisenleder DJ, Ferris HA \& Shupnik MA $2003 b$ The calcium component of $\mathrm{GnRH}$-stimulated LH subunit gene transcription is mediated by calcium/calmodulin-dependent protein kinase type II (Ca/CAMK II). Endocrinology 144 2409-2416.

Halvorson LM, Weiss J, Bauer-Dantoin AC \& Jameson JL 1994 Dynamic regulation of pituitary follistatin messenger ribonucleic acids during the rat estrous cycle. Endocrinology 134 1247-1253.

Halvorson LM, Kaiser UB \& Chin WW 1999 The protein kinase C system acts through the early growth response protein 1 to increase LHbeta gene expression in synergy with steroidogenic factor-1. Molecular Endocrinology 13 106-116.

Ham J, Jiang Z, Kravchenko VV \& Ulevitch RJ 1997 Activation of the transcription factor MEF2C by the MAP kinase p38 in inflammation. Nature 386 296-299.

Hamernik DL, Keri RA, Clay CM, Clay JN, Sherman GB, Sawyer HR Jr, Nett TM \& Nilson JH 1992 Gonadotrope- and thyrotrope-specific expression of the human and bovine glycoprotein hormone alpha-subunit genes is regulated by distinct cis-acting elements. Molecular Endocrinology 6 1745-1755.

Han XB \& Conn PM 1999 The role of PKA and PKC pathways in the regulation of MAPK activation in response to $\mathrm{GnRH}$ receptor activation. Endocrinology 140 2241-2251.

Hanson PI \& Schulman H 1992 Neuronal $\mathrm{Ca}^{2+}$ /calmodulindependent protein kinases. Annual Review of Biochemistry 61 559-601.

Heckert LL, Wilson EM \& Nilson JH 1997 Transcriptional repression of the alpha-subunit gene by androgen receptor occurs independently of DNA binding but requires the DNA-binding and ligand-binding domains of the receptor. Molecular Endocrinology 11 1497-1506.

Holl RW, Thorner MO, Mandell GL, Sullivan JA, Sinha YN \& Leong DA 1988 Spontaneous oscillations of intracellular calcium and GH secretion. Fournal of Biological Chemistry 263 9682-9685.

Hsieh KP \& Martin TF 1992 Thyrotropin-releasing hormone and gonadotropin-releasing hormone receptors activate phospholipase C by coupling to the guanosine triphosphate-binding proteins $\mathrm{Gq}$ and G11. Molecular Endocrinology 6 1673-1681.

Huang HJ, Sebastian J, Strahl BD, Wu JC \& Miller WL $2001 a$ The promoter for the ovine follicle-stimulating hormone-beta gene (FSHbeta) confers FSHbeta-like expression on luciferase in transgenic mice: regulatory studies in vivo and in vitro. Endocrinology 142 2260-2266.

Huang HJ, Sebastian J, Strahl BD, Wu JC \& Miller WL $2001 b$ Transcriptional regulation of the ovine follicle-stimulating hormone-beta gene by activin and gonadotropin-releasing hormone $(\mathrm{GnRH})$ : involvement of two proximal activator protein-1 sites for GnRH stimulation. Endocrinology 142 2267-2274.

Iliff-Sizemore SA, Ortolano GA, Haisenleder DJ, Dalkin AC, Krueger KA \& Marshall JC 1990 Testosterone differentially modulates gonadotropin subunit messenger ribonucleic acid responses to gonadotropin-releasing hormone pulse amplitude. Endocrinology 127 2876-2883.

Jorgensen JS \& Nilson JH 2001 a AR suppresses transcription of the alpha glycoprotein hormone subunit gene through protein-protein 
interactions with cJun and activation transcription factor 2. Molecular Endocrinology 15 1496-1504.

Jorgensen JS \& Nilson JH $2001 b$ AR suppresses transcription of the LH $\beta$ subunit by interacting with steroidogenic factor-1. Molecular Endocrinology 15 1505-1516.

Kaiser UB, Lee BL, Carroll RS, Unabia G, Chin WW \& Childs GV 1992 Follistatin gene expression in the pituitary: localization in gonadotropes and folliculostellate cells in diestrous rats. Endocrinology 130 3048-3056.

Kaiser UB \& Chin WW 1993 Regulation of follistatin messenger ribonucleic acid levels in the rat pituitary. Fournal of Clinical Investigation 91 2523-2531.

Kaiser UB, Conn PM \& Chin WW 1997a Studies of gonadotropin-releasing hormone $(\mathrm{GnRH})$ action using GnRH receptor-expressing pituitary cell lines. Endocrine Reviewes 18 46-70.

Kaiser UB, Jakubowiak A, Steinberger A \& Chin WW 1997 b Differential effects of gonadotropin-releasing hormone $(\mathrm{GnRH})$ pulse frequency on gonadotropin subunit and GnRH receptor messenger ribonucleic acid levels in vitro. Endocrinology 138 1224-1231.

Kaiser UB, Halvorson LM \& Chen MT 2000 Sp1, steroidogenic factor 1 (SF-1), and early growth response protein 1 (egr-1) binding sites form a tripartite gonadotropin-releasing hormone response element in the rat luteinizing hormone-beta gene promoter: an integral role for SF-1. Molecular Endocrinology 14 $1235-1245$.

Kato Y, Tomizawa K \& Kato T 1999 Multiple binding sites for nuclear proteins of the anterior pituitary located in the $5^{\prime}$-flanking region of the porcine FSH beta subunit gene. Molecular and Cellular Endocrinology 158 69-78.

Kawabata M, Imamura T, Inoue H, Hanai J, Nishihara A, Hanyu A, Takase M, Ishidou Y, Udagawa Y, Oeda E, Goto D, Yagi K, Kato M \& Miyazono K 1999 Intracellular signaling of the TGF-beta superfamily by Smad proteins. Annals of the New York Academy of Sciences $\mathbf{8 8 6} 73-82$.

Kawakami S \& Winters SJ 1999 Regulation of luteinizing hormone secretion and subunit messenger ribonucleic acid expression by gonadal steroids in perifused pituitary cells from male monkeys and rats. Endocrinology 140 3587-3593.

Kawakami S, Fujii Y, Okada Y \& Winters SJ 2002 Paracrine regulation of FSH by follistatin in folliculostellate cell-enriched primate pituitary cell cultures. Endocrinology 143 2250-2258.

Keri RA, Andersen B, Kennedy GC, Hamernik DL, Clay CM, Brace AD, Nett TM, Notides AC \& Nilson JH 1991 Estradiol inhibits transcription of the human glycoprotein hormone alpha-subunit gene despite the absence of a high affinity binding site for estrogen receptor. Molecular Endocrinology 5 725-733.

Keri RA, Wolfe MW, Saunders TL, Anderson I, Kendall SK, Wagner T, Yeung J, Gorski J, Nett TM, Camper SA \& Nilson JH 1994 The proximal promoter of the bovine luteinizing hormone beta-subunit gene confers gonadotrope-specific expression and regulation by gonadotropin-releasing hormone, testosterone, and $17 \beta$-estradiol in transgenic mice. Molecular Endocrinology 8 1807-1816.

Kerrigan JR, Dalkin AC, Haisenleder DJ, Yasin M \& Marshall JC 1993 Failure of gonadotropin-releasing hormone $(\mathrm{GnRH})$ pulses to increase luteinizing hormone beta messenger ribonucleic acid in GnRH-deficient female rats. Endocrinology 133 2071-2079.

Kerrigan JR, Yasin M, Haisenleder DJ, Dalkin AC \& Marshall JC 1995 Regulation of gonadotropin subunit messenger ribonucleic acid expression in gonadotropin-releasing hormone $(\mathrm{GnRH})$-deficient female rats: effects of $\mathrm{GnRH}$, galanin, GnRH-associated peptide, neuropeptide-Y, and thyrotropin-releasing hormone. Biology of Reproduction 53 1-7.

Kilen SM, Szabo M, Strasser GA, McAndrews JM, Ringstrom SJ \& Schwartz NB 1996 Corticosterone selectively increases follicle-stimulating hormone beta-subunit messenger ribonucleic acid in primary anterior pituitary cell culture without affecting its half-life. Endocrinology 137 3802-3807.

Kirk SE, Dalkin AC, Yasin M, Haisenleder DJ \& Marshall JC 1994 Gonadotropin-releasing hormone pulse frequency regulates expression of pituitary follistatin messenger ribonucleic acid: a mechanism for differential gonadotrope function. Endocrinology 135 876-880.

Kogawa K, Nakamura T, Sugino K, Takio K, Titani K \& Sugino H 1991 a Activin-binding protein is present in pituitary. Endocrinology 128 1434-1440.

Kogawa K, Ogawa K, Hayashi Y, Nakamura T, Titani K \& Sugino H $1991 b$ Immunohistochemical localization of follistatin in rat tissues. Endocrinologia Faponica 38 383-391.

Kumar TR \& Low MJ 1993 Gonadal steroid hormone regulation of human and mouse follicle stimulating hormone beta-subunit gene expression in vivo. Molecular Endocrinology 7 898-906.

Kumar TR \& Low MJ 1995 Hormonal regulation of human follicle-stimulating hormone-beta subunit gene expression: $\mathrm{GnRH}$ stimulation and GnRH-independent androgen inhibition. Neuroendocrinology $61628-637$.

Kumar TR, Fairchild-Huntress V \& Low MJ 1992 Gonadotrope-specific expression of the human follicle-stimulating hormone beta-subunit gene in pituitaries of transgenic mice. Molecular Endocrinology 6 81-90.

Lagna G, Hata A, Hemmati-Brivanlou A \& Massague J 1996 Partnership between DPC4 and SMAD proteins in TGF- $\beta$ signaling pathways. Nature 383 832-836.

Leal AM, Blount AL, Donaldson CJ, Bilezikjian LM \& Vale WW 2003 Regulation of follicle-stimulating hormone secretion by the interactions of activin-A, dexamethasone and testosterone in anterior pituitary cell cultures of male rats. Neuroendocrinology $\mathbf{7 7}$ 298-304.

Lee S \& Rivier C 1997 Effect of repeated activin-A treatment on the activity of the hypothalamic-pituitary-gonadal axis of the adult male rat. Biology of Reproduction 56 969-975.

Levi NL, Hanoch T, Benard O, Rozenblat M, Harris D, Reiss N, Naor Z \& Seger R 1998 Stimulation of Jun N-terminal kinase (JNK) by gonadotropin-releasing hormone in pituitary alpha T3-1 cell line is mediated by protein kinase C, c-Src, and CDC42. Molecular Endocrinology 12 815-824.

Levine JE \& Duffy MT 1988 Simultaneous measurement of luteinizing hormone (LH)-releasing hormone, $\mathrm{LH}$, and follicle-stimulating hormone release in intact and short-term castrate rats. Endocrinology 122 2211-2221.

Levine JE \& Ramirez VD 1982 Luteinizing hormone-releasing hormone release during the rat estrous cycle and after ovariectomy, as estimated with push-pull cannulae. Endocrinology 111 1439-1448.

Lewis KA, Gray PC, Blount AL, MacConell LA, Wiater E, Bilezikjian LM \& Vale W 2000 Betaglycan binds inhibin and can mediate functional antagonism of activin signalling. Nature $\mathbf{4 0 4}$ $411-414$.

Lin X \& Conn PM 1999 Transcriptional activation of GnRH receptor gene by GnRH: involvement of multiple signal transduction pathways. Endocrinology 140 358-364.

Ling N, Ying SY, Ueno N, Shimasaki S, Esch F, Hotta M \& Guillemin R 1986 A homodimer of the beta-subunits of inhibin A stimulates the secretion of pituitary follicle stimulating hormone. Biochemical and Biophysical Research Communications 138 1129-1137.

Liu F, Austin DA, Mellon PL, Olefsky JM \& Webster NJ $2002 a$ GnRH activates ERK1/2 leading to the induction of c-fos and LHbeta protein expression in LBT2 cells. Molecular Endocrinology 16 419-434.

Liu F, Usui I, Evans LG, Austin DA, Mellon PL, Olefsky JM \& Webster NJ $2002 b$ Involvement of Both Gq/11 and Gs Proteins 
in gonadotropin-releasing hormone receptor-mediated signaling in LBT2 cells. Fournal of Biological Chemistry 277 32099-32108.

MacConell LA, Leal AM \& Vale WW 2002 The distribution of betaglycan protein and mRNA in rat brain, pituitary, and gonads: implications for a role for betaglycan in inhibin-mediated reproductive functions. Endocrinology 143 1066-1075.

Marshall JC \& Kelch RP 1986 GnRH: role of pulsatile secretion in the regulation of reproduction. New England Fournal of Medicine 315 1459-1468.

Mather JP, Moore A \& Li RH 1997 Activins, inhibins, and follistatins: further thoughts on a growing family of regulators. Proceedings of the Society for Experimental Biology and Medicine 215 209-222.

Matzuk MM, Lu N, Vogel H, Sellheyer K, Roop DR \& Bradley A 1995 Multiple defects and perinatal death in mice deficient in follistatin. Nature 374 360-363.

Maurer RA, Kim KE, Schoderbek WE, Roberson MS \& Glenn DJ 1999 Regulation of glycoprotein hormone alpha-subunit gene expression. Recent Progress in Hormone Research 54 455-484.

McAndrews JM, Ringstrom SJ, Dahl KD \& Schwartz NB 1994 Corticosterone in vivo increases pituitary follicle-stimulating hormone (FSH)-beta messenger ribonucleic acid content and serum FSH bioactivity selectively in female rats. Endocrinology 134 158-163.

McDowell N \& Gurdon JB 1999 Activin as a morphogen in Xenopus mesoderm. Seminars in Cell and Developmental Biology 10 311-317.

McNeilly JR, Brown P, Mullins J, Clark AJ \& McNeilly AS 1996 Characterization of the ovine LH beta-subunit gene: the promoter is regulated by $\mathrm{GnRH}$ and gonadal steroids in transgenic mice. fournal of Endocrinology 151 481-489.

Mercer JE, Clements JA, Funder JW \& Clarke IJ 1989 Regulation of follicle-stimulating hormone beta and common alpha-subunit messenger ribonucleic acid by gonadotropin-releasing hormone and estrogen in the sheep pituitary. Neuroendocrinology 50 321-326.

Meunier H, Rivier C, Evans RM \& Vale W 1988 Gonadal and extragonadal expression of inhibin alpha, beta $\mathrm{A}$, and beta $\mathrm{B}$ subunits in various tissues predicts diverse functions. PNAS $\mathbf{8 5}$ $247-251$.

Miller CD \& Miller WL 1996 Transcriptional repression of the ovine follicle-stimulating hormone-beta gene by 17 beta-estradiol. Endocrinology 137 3437-3446.

Miller SG \& Kennedy MB 1986 Regulation of brain type II $\mathrm{Ca}^{2+} /$ calmodulin-dependent protein kinase by autophosphorylation: a $\mathrm{Ca}^{2+}$-triggered molecular switch. Cell $\mathbf{4 4}$ 861-870.

Mitchell R, Sim PJ, Leslie T, Johnson MS \& Thomson FJ 1994 Activation of MAP kinase associated with the priming effect of LHRH. Fournal of Endocrinology 140 R15-R18.

Mulvaney JM, Zang T, Fewtrell C \& Roberson MS 1999 Calcium influx through L-type channels is required for selective activation of extracellular signal-regulated kinase by GnRH. Fournal of Biological Chemistry 274 29796-29804.

Munz B, Tretter YP, Hertel M, Engelhardt F, Alzheimer C \& Werner S 2001 The roles of activins in repair processes of the skin and the brain. Molecular and Cellular Endocrinology 180 169-177.

Nakamura T, Takio K, Eto Y, Shibai H, Titani K \& Sugino H 1990 Activin-binding protein from rat ovary is follistatin. Science 247 836-838.

Naor Z 1990 Signal transduction mechanisms of $\mathrm{Ca}^{2+}$ mobilizing hormones: the case of gonadotropin-releasing hormone. Endocrine Revieres 11 326-353.

Neill JD 2002 Minireview: GnRH and GnRH receptor genes in the human genome. Endocrinology 143 737-743.

Norwitz ER, Cardona GR, Jeong KH \& Chin WW 1999 Identification and characterization of the gonadotropin-releasing hormone response elements in the mouse gonadotropin-releasing hormone receptor gene. Fournal of Biological Chemistry 274 867-880.

Nowakowski BE, Okimura Y \& Maurer RA 1997 Characterization of DNA regions mediating the ability of $\mathrm{Ca}^{2+}$ /calmodulin dependent protein kinase II to stimulate prolactin promoter activity. Molecular and Cellular Endocrinology 132 109-116.

O'Conner JL, Wade MF, Edwards DP \& Mahesh VB 1999 Progesterone and regulation of the follicle-stimulating hormone (FSH-beta) gene. Steroids 64 592-597.

O'Conner JL, Wade MF, Prendergast P, Edwards DP, Boonyaratanakornkit V \& Mahesh VB 1997 A 361 base pair region of the rat FSH-beta promoter contains multiple progesterone receptor-binding sequences and confers progesterone responsiveness. Molecular and Cellular Endocrinology 136 67-78.

Ortolano GA, Haisenleder DJ, Dalkin AC, Iliff-Sizemore SA, Landefeld TD, Maurer RA \& Marshall JC 1988 Follicle-stimulating hormone beta subunit messenger ribonucleic acid concentrations during the rat estrous cycle. Endocrinology 123 2946-2948.

Pangus SA \& Woodruff TK 2000 Activin signal transduction pathways. Trends in Endocrinology and Metabolism 11 309-314.

Papavasiliou SS, Zmeili S, Herbon L, Duncan-Weldon J, Marshall JC \& Landefeld TD 1986 Alpha and luteinizing hormone beta messenger ribonucleic acid (RNA) of male and female rats after castration: quantitation using an optimized RNA dot blot hybridization assay. Endocrinology 119 691-698.

Park D, Cheon M, Kim C, Kim K \& Ryu K 1996 Progesterone together with estradiol promotes luteinizing hormone beta-subunit mRNA stability in rat pituitary cells cultured in vitro. European Fournal of Endocrinology 134 236-242.

Paul SJ, Ortolano GA, Haisenleder DJ, Stewart JM, Shupnik MA \& Marshall JC 1990 Gonadotropin subunit messenger RNA concentrations after blockade of gonadotropin-releasing hormone action: testosterone selectively increases follicle-stimulating hormone beta-subunit messenger RNA by posttranscriptional mechanisms. Molecular Endocrinology 4 1943-1955.

Pernasetti F, Vasilyev VV, Rosenberg SB, Bailey JS, Huang HJ, Miller WL \& Mellon PL 2001 Cell-specific transcriptional regulation of follicle-stimulating hormone-beta by activin and gonadotropin-releasing hormone in the L $\beta \mathrm{T} 2$ pituitary gonadotrope cell model. Endocrinology 142 2284-2295.

Phillips CL, Lin LW, Wu JC, Guzman K, Milsted A \& Miller WL 198817 Beta-estradiol and progesterone inhibit transcription of the genes encoding the subunits of ovine follicle-stimulating hormone. Molecular 2 641-649.

Phillips DJ, Jones KL, Scheerlinck JY, Hedger MP \& de Kretser DM 2001 Evidence for activin A and follistatin involvement in the systemic inflammatory response. Molecular and Cellular Endocrinology $180155-162$.

Plendl J 2000 Angiogenesis and vascular regression in the ovary. Anatomia, Histologia, Embryologia: Veterinary Medicine Series C 29 257-266.

Prendergast KA, Burger LL, Aylor KW, Haisenleder DJ, Dalkin AC \& Marshall JC 2003 Pituitary follistatin gene expression in female rats: evidence that inhibin regulates transcription. Biology of Reproduction $70364-370$.

Quirk CG, Lozada KL, Keri RA \& Nilson JH 2001 A single Pitxl binding site is essential for activity of the LH $\beta$ promoter in transgenic mice. Molecular Endocrinology 15 734-746.

Reiss N, Llevi LN, Shacham S, Harris D, Seger R \& Naor Z 1997 Mechanism of MAPK activation by GnRH in the pituitary alpha T-3 cell line: differential roles of calcium and PKC. Endocrinology 138 1673-1682.

Riggins GJ, Thiagalingam S, Rozenblum E, Weinstein CL, Kern SE, Hamilton SR, Willson JK, Markowitz SD, Kinzler KW \& Vogelstein B 1996 MAD-related genes in the human. Nature Genetics 13 347-349. 
Ringstrom SJ, McAndrews JM, Rahal JO \& Schwartz NB 1991 Cortisol in vivo increases FSH beta mRNA selectively in pituitaries of male rats. Endocrinology 129 2793-2795.

Ringstrom SJ, Szabo M, Kilen SM, Saberi S, Knox KL \& Schwartz NB 1997 The antiprogestins RU486 and ZK98299 affect follicle-stimulating hormone secretion differentially on estrus, but not on proestrus. Endocrinology 138 2286-2290.

Rivier C, Schwall R, Mason A, Burton L \& Vale W 1991 Effect of recombinant inhibin on gonadotropin secretion during proestrus and estrus in the rat. Endocrinology 128 2223-2228.

Roberson MS, Misra-Press A, Laurance ME, Stork PJS \& Maurer RA 1995 A role for mitogen-activated protein kinase in mediating activation of the glycoprotein hormone $\alpha$-subunit promoter by GnRH. Molecular and Cellular Biology 15 3531-3539.

Roberson MS, Zhang T, Li HL \& Mulvaney JM 1999 Activation of the p38 mitogen-activated protein kinase pathway by gonadotropin-releasing hormone. Endocrinology 140 $1310-1318$.

Roberts V, Meunier H, Vaughan J, Rivier J, Rivier C, Vale W \& Sawchenko P 1989 Production and regulation of inhibin subunits in pituitary gonadotropes. Endocrinology 124 552-554.

Salton SRJ, Blum M, Jonassen JA, Clayton RN \& Roberts JL 1988 Stimulation of pituitary luteinizing hormone secretion by gonadotropin-releasing hormone is not coupled to $\beta$-luteinizing hormone gene transcription. Molecular Endocrinology 2 1033-1042.

Saunders BD, Sabbagh E, Chin WW \& Kaiser UB 1998 Differentia use of signal transduction pathways in the gonadotropin-releasing hormone-mediated regulation of gonadotropin subunit gene expression. Endocrinology 139 1835-1843.

Schulman H, Heist K \& Srinivasan M 1995 Decoding Ca ${ }^{2+}$ signals to the nucleus by multifunctional CaM kinase. Progress in Brain Research 105 95-104.

Seger R \& Krebs EG 1995 The MAPK signaling cascade. FASEB Fournal 9 726-735.

Shi Y \& Massague J 2003 Mechanisms of TGF-beta signaling from cell membrane to the nucleus. Cell 113 685-700.

Shimonaka M, Inouye S, Shimasaki S \& Ling N 1991 Follistatin binds to activin and inhibin through the common beta subunit. Endocrinology 130 3048-3056.

Shupnik MA 1990 GnRH effects on rat gonadotropin gene transcription in vitro: requirement for pulsatile administration for LH- $\beta$ gene stimulation. Molecular Endocrinology 4 1444-1450.

Shupnik MA 1996 Gonadotropin gene modulation by steroids and gonadotropin-releasing hormone. Biology of Reproduction $\mathbf{5 4}$ 279-286.

Shupnik MA \& Fallest PC 1994 Pulsatile GnRH regulation of gonadotropin subunit gene transcription. Neuroscience and Biobehavioral Reviews 18 597-599.

Shupnik MA \& Rosenzweig BA 1991 Identification of an estrogen-responsive element in the rat LH beta gene. DNA-estrogen receptor interactions and functional analysis. Journal of Biological Chemistry 266 17084-17091.

Shupnik MA, Gharib SD \& Chin WW 1988 Estrogen suppresses rat gonadotropin gene transcription in vivo. Endocrinology 122 1842-1846.

Shupnik MA, Gharib SD \& Chin WW 1989a Divergent effects of estradiol on gonadotropin gene transcription in pituitary fragments. Molecular Endocrinology 3474480.

Shupnik MA, Weinmann CM, Notides AC \& Chin WW 1989b An upstream region of the rat luteinizing hormone beta gene binds estrogen receptor and confers estrogen responsiveness. Fournal of Biological Chemistry 264 80-86.

Simard J, Labrie C, Hubert JF \& Labrie F 1988 Modulation by sex steroids and [D-Trp6, Des-Gly-NH2(10)]luteinizing hormone (LH)-releasing hormone ethylamide of alpha-subunit and LH beta messenger ribonucleic acid levels in the rat anterior pituitary gland. Molecular Endocrinology 2 775-784.
Spady TJ, Shayya R, Thackray VG, Ehrensberger L, Bailey JS \& Mellon PL 2004 Androgen regulates follicle-stimulating hormone $\beta$ gene expression in an activin-dependent manner in immortalized gonadotropes. Molecular Endocrinology 18 925-940.

Stojilkovic SS \& Catt KJ 1995 a Novel aspects of GnRH-induced intracellular signaling and secretion in pituitary gonadotrophs. Fournal of Neuroendocrinology 7 739-757.

Stojilkovic SS \& Catt KJ $1995 b$ Expression and signal transduction pathways of GnRH receptors. Recent Progress in Hormone Research $\mathbf{5 0}$ 161-205.

Strahl BD, Huang HJ, Sebastian J, Ghosh BR \& Miller WL 1998 Transcriptional activation of the ovine follicle-stimulating hormone beta-subunit gene by gonadotropin-releasing hormone: involvement of two activating protein-1-binding sites and protein kinase C. Endocrinology 139 4455-4465.

Sundaresan S, Colin IM, Pestell RG \& Jameson JL 1996 Stimulation of MAPK by GnRH: evidence for the involvement of PKC. Endocrinology 137 304-311.

Suszko MI, Lo DJ, Suh H, Camper SA \& Woodruff TK 2003 Regulation of the rat follicle-stimulating hormone $\beta$-subunit promoter by activin. Molecular Endocrinology 17 318-332.

Tremblay JJ \& Drouin J 1999 Egr-1 is a downstream effector of GnRH and synergizes by direct interaction with Ptxl and SF-1 to enhance luteinizing hormone beta gene transcription. Molecular and Cellular Biology 19 2567-2576.

Tse A \& Hille B 1992 GnRH-induced calcium oscillations and rhythmic hyperpolarizations of pituitary gonadotropes. Science $\mathbf{2 5 5}$ 462-464.

Turgeon JL, Kimura Y, Waring DW \& Mellon PL 1996 Steroid and pulsatile gonadotropin-releasing hormone $(\mathrm{GnRH})$ regulation of luteinizing hormone and $\mathrm{GnRH}$ receptor in a novel gonadotrope cell line. Molecular Endocrinology $10439-450$.

Vale W, Rivier J, Vaughan J, McClintock R, Corrigan A, Woo W, Karr D \& Spiess J 1986 Purification and characterization of an FSH releasing protein from porcine ovarian follicular fluid. Nature $321776-779$

Vasilyev VV, Lawson MA, Dipaolo D, Webster NJ \& Mellon PL $2002 a$ Different signaling pathways control acute induction versus long-term repression of LH beta transcription by GnRH. Endocrinology 143 3414-3426.

Vasilyev VV, Pernasetti F, Rosenberg SB, Barsoum MJ, Austin DA, Webster NJG \& Mellon PL $2002 b$ Transcriptional activation of the ovine FSH beta gene by GnRH involves multiple signal transduction pathways. Endocrinology 143 1651-1659.

Villalobos C, Faught WJ \& Frawley LS 1998 Dynamic changes in spontaneous intracellular free calcium oscillations and their relationship to prolactin gene expression in single, primary mammotropes. Molecular Endocrinology 12 87-95.

Webster JC, Pedersen NR, Edwards DP, Beck CA \& Miller WL 1995 The $5^{\prime}$-flanking region of the ovine follicle-stimulating hormone-beta gene contains six progesterone response elements: three proximal elements are sufficient to increase transcription in the presence of progesterone. Endocrinology 136 1049-1058.

Weck J, Fallest PG, Pitt LK \& Shupnik MA 1998 Differential gonadotropin-releasing hormone stimulation of rat luteinizing hormone subunit gene transcription by calcium influx and mitogen-activated protein kinase-signaling pathways. Molecular Endocrinology 12 451-457.

Weck J, Anderson AC, Jenkins S, Fallest PC \& Shupnik MA 2000 Divergent and composite gonadotropin-releasing hormone-responsive elements in the rat luteinizing hormone subunit genes. Molecular Endocrinology 14 472-485.

Weiss J, Jameson JL, Burrin JM \& Crowley WF 1990 Divergent responses of gonadotropin subunit messenger RNAs to continuous versus pulsatile gonadotropin-releasing hormone in vitro. Molecular Endocrinology 4 557-564. 
Weiss J, Crowley WF \& Jameson JL 1992 Pulsatile gonadotropin-releasing hormone modifies polyadenylation of gonadotropin subunit messenger ribonucleic acids. Endocrinology $130415-420$

Weiss J, Crowley WF Jr, Halvorson LM \& Jameson JL 1993 Perifusion of rat pituitary cells with gonadotropin-releasing hormone, activin, and inhibin reveals distinct effects on gonadotropin gene expression and secretion. Endocrinology 132 2307-2311.

Weiss J, Guendner MJ, Halvorson LM \& Jameson JL 1995 Transcriptional activation of the follicle-stimulating hormone $\beta$-subunit gene by activin. Endocrinology 136 1885-1891.

White BR, Duval DL, Mulvaney JM, Roberson MS \& Clay CM 1999 Homologous regulation of the gonadotropin-releasing hormone receptor gene is partially mediated by protein kinase $\mathrm{C}$ activation of an activator protein-1 element. Molecular Endocrinology 13 566-577.

Whitmarsh AJ, Yang SH, Su MSS, Sharrocks AD \& Davis RJ 1997 Role of p38 and JNK MAP kinases in the activation of ternary complex factors. Molecular and Cellular Biology 17 2360-2371.

Wierman ME \& Wang C 1990 Androgen selectively stimulates follicle-stimulating hormone-beta mRNA levels after gonadotropin-releasing hormone antagonist administration. Biology of Reproduction 42 563-571.

Wierman ME, Gharib SD, LaRovere JM, Badger TM \& Chin WW 1988 Selective failure of androgens to regulate follicle stimulating hormone beta messenger ribonucleic acid levels in the male rat. Molecular Endocrinology 2 492-498.

Wierman ME, Gharib SD, Wang C, LaRovere JM, Badger TM \& Chin WW 1990 Divergent regulation of gonadotropin subunit mRNA levels by androgens in the female rat. Biology of Reproduction 43 191-195.

Winters SJ, Ishizaka K, Kitahara S, Troen P \& Attardi B 1992 Effects of testosterone on gonadotropin subunit messenger ribonucleic acids in the presence or absence of gonadotropin-releasing hormone. Endocrinology 130 726-734.

Winters SJ, Dalkin AC \& Tsuji T 1997 Evidence that pituitary adenylate cyclase activating polypeptide suppresses follicle-stimulating hormone-beta messenger ribonucleic acid levels by stimulating follistatin gene transcription. Endocrinology 134 $4324-4329$.

Winters SJ, Kawakami S, Sahu A \& Plant TM 2001 Pituitary follistatin and activin gene expression, and the testicular regulation of FSH in the adult rhesus monkey (Macaca mulatta). Endocrinology 142 2874-2878.

Wolfe M \& Call GB 1999 Egr-1 binds the LH beta promoter and mediates GnRH-stimulated gene expression. Molecular Endocrinology $13752-763$.

Woodruff TK, Besecke LM, Groome N, Draper LB, Schwartz NB \& Weiss J 1996 Inhibin A and inhibin B are inversely correlated to follicle-stimulating hormone, yet are discordant during the follicular phase of the rat estrous cycle, and inhibin A is expressed in a sexually dimorphic manner. Endocrinology 137 5463-5467.

Woodruff TK, Krummen LA, Lyon RJ, Stocks DL \& Mather J 1993 Recombinant human inhibin $\mathrm{A}$ and recombinant human activin A regulate pituitary and ovarian function in the adult female rat. Endocrinology 132 2332-2341.

Wu FCW, Butler GE, Kelnar CJH \& Sellar RE 1990 Patterns of pulsatile LH secretion before and during the onset of puberty in boys: a study using an immunoradiometric assay. Fournal of Clinical Endocrinology and Metabolism 70 629-637.

Yasin M, Dalkin AC, Haisenleder DJ \& Marshall JC 1996 Testosterone is required for gonadotropin-releasing hormone stimulation of luteinizing hormone-beta messenger ribonucleic acid expression in female rats. Endocrinology 137 1265-1271.

Yingling JM, Datto MB, Wong C, Frederick JP, Liberati NT \& Wang XF 1997 Tumor suppressor Smad4 is a transforming growth factor beta-inducible DNA binding protein. Molecular and Cellular Biology 17 7019-7028.

Yokoi T, Ohmichi M, Tasaka K, Kimura A, Kanda Y, Hayakawa J, Tahara M, Hisamoto K, Kurachi H \& Murata Y 2000 Activation of the luteinizing hormone beta promoter by gonadotropin-releasing hormone requires c-Jun NH2-terminal protein kinase. Fournal of Biological Chemistry 275 21639-21647.

Zhang Y, Feng X, We R \& Derynck R 1996 Receptor-associated MAD homologues synergize as effectors of the TGF-beta response. Nature 383 168-172.

Zmeili SM, Papavasiliou SS, Thorner MO, Evans WS, Marshall JC \& Landefeld TD 1986 Alpha and luteinizing hormone beta subunit messenger ribonucleic acids during the rat estrous cycle. Endocrinology 119 1867-1869.

Received 30 June 2004

Accepted 23 August 2004

Made available online as an Accepted Preprint 3 September 2004 